\title{
International Financial Regulation: Why It Still Falls Short
}

\author{
William White*
}

\section{Working Paper No. 131}

July $25^{\text {th }}, 2020$

\begin{abstract}
While recent reforms are welcome in many ways, there are still significant reasons to doubt that the post-crisis tightening of international financial regulation guarantees future financial and economic stability. The most important reason is that the reforms have focused too narrowly on ensuring that an unstable financial sector will not aggravate downturns by restricting the supply of credit. More attention needs to be paid to ensuring that an overly exuberant financial system does not weaken other parts of the economy by encouraging a rapid buildup of debt during upturns. Some combination of time-varying monetary and regulatory policies (a macrofinancial stability framework) will be required to do this. In addition, many of the individual regulatory measures taken to date, both macroprudential and microprudential, have shortcomings. Their coherence as a package has also been questioned.
\end{abstract}

\section{https://doi.org/10.36687/inetwp131}

JEL Codes: E02, E32, E42, E52, E58

Keywords: Too big to fail, financial safety, financial reform, financial crises, implicit subsidies, political economy

\footnotetext{
${ }^{*}$ Senior Fellow, C D Howe Institute (Toronto) and former Economic Adviser, Bank for International Settlements (Basel). The views expressed in this paper are those of the author and do not necessarily reflect the views of any institutions with which he has been associated. The author would like to thank Charles Goodhart, Desmond Lachman, Robert Pringle, James Stewart, Leslaw Skoczylas, Dirk Schoenmaker and Andrew Smithers for helpful comments without suggesting agreement with his conclusions.
} 


\section{Introduction and Summary}

The financial and economic crisis that began in 2007 was shocking, not just because of its magnitude and eventual duration, but because it was to such a large degree unexpected. Preceded as it was by the "Great Moderation," some influential commentators had even suggested that the business cycle had been banished for good. Reinforcing the element of surprise, the economic models that were in widest use implied that crises, followed by long periods of sub par economic performance, were essentially impossible. Notably, these models were focused on developments in the real economy and ignored financial developments almost entirely.

Searching for an explanation for this unexpected event, attention quickly focused on the previously ignored operations of the financial system as "somehow" the cause of the crisis. One response was to try to introduce a financial sector and financial frictions into the economic models used by policymakers ${ }^{1}$. Another response was to tighten the regulations affecting the financial sector with a view to reducing the likelihood of future crises and moderating the economic costs should they occur. An immense international effort was mounted, centred around the Basel based institutions ${ }^{2}$, but involving virtually every country in the world.

The purpose of this paper is to evaluate whether those internationally driven regulatory changes, focused largely on banks, seem likely to have achieved their objectives. The conclusion drawn is that the likelihood and cost of future crises, whether in the financial sector or the broader economy, have not been adequately reduced. ${ }^{3}$ One reason is that the individual changes have shortcomings and their coherence as a package can also be questioned. However, a more fundamental reason is that the post-crisis regulatory changes have had too narrow a focus.

The primary objective sought has been to ensure that a weak financial system does not aggravate economic downturns, by restricting the supply of credit. Arguably more important, and having received some but much less attention, is the need to ensure that an overly exuberant financial system does not weaken other parts of the economy by encouraging a rapid buildup of debt during upturns. This aggravates the subsequent downturn by limiting the demand for credit.

The only policy that would suffice to avoid both problems is to "lean against the wind" of debt accumulation in the upswing of the credit cycle. It will be argued below that we need a macrofinancial stability framework to do this effectively. Both monetary policy and macroprudential regulatory policy must be used in a way that reflects their relative strengths and weaknesses. Without monetary support, regulatory restrictions will be circumvented. Without the support of macroprudential policies, monetary tightening alone might prove destructive for the whole economy.

\footnotetext{
${ }^{1}$ For an overview, see Haley (2020).

${ }^{2}$ The Bank for International Settlements in Basel hosts the Financial Stability Board, the Basel Committee on Banking Supervision and a number of other committees and organizations. Broadly put, these groups lay out international guidelines for regulatory reform, while national authorities, with the support of the IMF and OECD, try to enforce them.

${ }^{3}$ See White (2014) for a more narrowly focused, but much more detailed analysis.
} 
However, such a framework has not been adopted in most large countries or monetary jurisdictions. As before the crisis, monetary policy post-crisis has remained firmly directed to the pursuit of near-term price stability. Nor are there any indications this objective might be altered going forward. This is unfortunate since, as argued in White (2016), the relentless pursuit of near-term price stability by central banks has in fact put the global economy on an unsustainable path. Against a backdrop of disinflationary supply side shocks, since the late 1980s, excessive recourse to monetary easing has encouraged imprudent financial behavior leading to a rising stock of debt and other "imbalances" which have negatively affected both the real and financial sectors of the economy.

Cycle after cycle, monetary policy has been conducted in a profoundly asymmetrical fashion. In upswings, the growth of debt has been insufficiently restrained by rising rates. In downturns, sharply lower rates have created the illusion that this increased debt is sustainable. In effect, the policy regime has encouraged the belief that economies face liquidity problems when the underlying problem is really one of growing insolvency. Moreover, policy rates have ratcheted down, cycle after cycle, to an effective lower bound, which has encouraged the use of ever more experimental instruments of monetary stimulus. In effect, the path we are on is unsustainable because the underlying problems grow endogenously worse over time while the solutions become ever more constrained.

Central banks support for the monetary status quo has been bolstered by the belief that macroprudential regulatory policies, used alone, would be sufficient to deal with problems associated with the excessive growth of credit and debt. However, this belief can be disputed on many fronts. ${ }^{4}$ Macroprudential policies should properly be defined as policies focused on the stability of the economic system as a whole. However, in practice, policymakers have focused much more narrowly on measures to ensure the stability of the financial system alone. Unfortunately, spurred by easy monetary conditions, dangerous "imbalances" can also build up outside of the financial sector, not least in the form of unsustainable household and corporate debt.

Even accepting the limited focus on financial sector stability, the-time varying macroprudential measures suggested to deal with excessively rapid credit creation have serious shortcomings. Moreover, other (non time-varying) macroprudential policies, designed to reduce the systemic implications of institutional interdependencies and the "too big to fail" problem, have only partly achieved their objectives.

The reality is that most of the post-crisis reform effort has gone into traditional microprudential regulatory policies. ${ }^{5}$ Such policies also do not vary over time and, by definition, cannot "lean against the wind." Moreover, microprudential policies seek to strengthen the health of individual institutions, rather than the stability of the financial system as a whole. Thus, they are two steps away from the ideal of countercyclical policies directed to stabilizing the broader economic system. In this regard, the regulators and the central banks have both retreated into post-crisis

\footnotetext{
${ }^{4}$ White (2019).

${ }^{5}$ See Borio et al. (2020) who state (p. 9) "International regulatory standards were entirely microprudential pre-crisis and continue to be largely such."
} 
policies that focus on cleaning up after a crisis (promoting resilience) rather than leaning against it (promoting sustainability). In effect, post-crisis policies have essentially been "more of the same" policies that put the economy on an unsustainable path in the first place.

Some of the post-crisis microprudential initiatives have clearly been helpful, but certain shortcomings can also be identified. Not least, tighter regulations of institutions by sector invites migration to less regulated sectors as well as encouraging innovations specifically designed to avoid the regulations. For example, pre-crisis regulation of banks contributed to the growth of a particular form of "shadow banking." Since the crisis, the rapid growth of asset management companies has raised questions about the risks they might now pose to the global financial system.

With so much regulatory reform since the crisis, but with so many fears still remaining about possible future instability, it seems legitimate to ask whether more fundamental changes are required? It is suggested in this paper that we begin by addressing the shortcomings already noted in how the current system operates. This implies introducing a macro-financial stability framework, and then complementing it with other reforms directly targeting other identified problems. However, others suggest this approach is not radical enough. It deals only with symptoms and not the underlying problem - the nature of our current "fiat money" system. Many critics argue that the capacity of national financial systems to create money out of nothing is the root cause of the problem of excessive credit and debt creation. Still others bemoan the absence of an International Monetary System that might force discipline on the national authorities participating in it.

This paper focuses exclusively on how forces leading to increased debt and "imbalances" might be resisted in the future (crisis prevention). ${ }^{6}$ However, policymakers must also face another and more immediate challenge. How should they deal with the current crisis (crisis management), triggered by the covid-19 pandemic, but made worse by all the "imbalances" arising from the excessive reliance on easy monetary policy in the past? Moreover, what policy solutions might support a more sustainable recovery (crisis resolution) than the monetary solutions relied upon in the past?

Unfortunately, unprecedented monetary stimulus in the post-crisis period, justified by the undershooting of inflation targets, has further aggravated these unsustainable tendencies. In particular, the debt problem has taken on a truly global dimension in just the last few years. This made future crises both more likely and more costly: an accident waiting to happen. While the covid-19 pandemic has now triggered this crisis, the crucial observation is that the patient already had pre-existing conditions and that the policy response to the pandemic has made these conditions worse. The fact that many governments have sharply expanded their fiscal deficits, in response to the pandemic, indicates a growing and welcome acceptance that too much reliance has been put on monetary stimulus in the past. However, sovereign debt expansion also has its

\footnotetext{
${ }^{6}$ A related question is also outside the scope of this paper. What institutional reforms might be needed to implement different polices directed to crisis prevention? In particular, what would be the implications for the "independence" of central banks?
} 
limits. While beyond the scope of this paper, the modalities of debt restructuring, in both the public and private sector, need far more attention than they have received so far.

\section{The Financial Cycle and the Real Economy}

There is now an extensive literature on "boom-bust" financial cycles throughout history. ${ }^{7}$ They have occurred recurrently under a variety of regulatory and monetary regimes. A common theme is some piece of good news in the real economy that seems to justify higher expectations of profits and more investment financed by rapid credit expansion. ${ }^{8}$ Rising prices for financial assets and real estate provide more collateral for still more lending. Momentum trading and rising enthusiasm provide more positive feedback ("procyclicality") until interest rates begin to rise and expectations are eventually reassessed as unrealistic. These developments raise doubts about the capacity of highly leveraged borrowers to service debts. This often triggers a "Minsky moment," preceded by a period of credit deceleration, in which private sector credit dries up and boom turns into bust. ${ }^{9}$

This literature clearly implies that achieving price stability (a sustained low level of inflation) is not sufficient to ensure stability in the real economy. ${ }^{10}$ Moreover, recent history also supports this view. Indeed, the last three major economic downturns (1990, 2001 and 2008) did not have their origins in central bank tightening in response to sharply rising inflation. Rather, they had their origins in high and rising debt levels and associated disturbances in financial markets. The financial cycle should by now have displaced the business cycle as the chief source of concern for central bankers. Unfortunately, this crucial lesson does not yet seem to have been learned.

The relatively slow recovery from credit driven busts also has its roots in the burden of debt built up in the preceding period of the boom. ${ }^{11}$ Monetary policy works largely by bringing spending forward from the future to today. ${ }^{12}$ However, in this process, debts are accumulated which constitute claims against future spending. As tomorrow becomes today, the weight of those debt claims on aggregate demand steadily increases. ${ }^{13}$ Attempts to service debt take priority and lead to expenditure cutbacks by debtors which are not matched by the increased expenditures of creditors. ${ }^{14}$ Through the Keynesian "paradox of thrift," this behavior stifles growth. Economic

\footnotetext{
${ }^{7}$ A classic reference to this history is Kindleberger and Aliber (2005). Early post-crisis historical studies are by Reinhart and Rogoff (2009) and Schularick and Taylor (2012).

${ }^{8}$ The likelihood of this happening rises as memories of past crises, associated with such behavior, fade over time.

${ }^{9}$ Perhaps the most compelling theoretical exposition of this process is provided by Minsky (1986) who emphasizes the importance of both private debt accumulation and changes in income distribution in affecting system dynamics. Keen began suggesting formal models of these non-linear processes many decades ago. See Keen (1995) and, most recently, Keen (2017).

${ }^{10}$ Complementary arguments to support this conclusion are presented in White (2006).

${ }^{11}$ For a lengthy discussion see Reinhart and Reinhart (2010).

${ }^{12}$ For a much more detailed description of the various channels through which monetary policy is thought to affect aggregate demand, see White (2016).

${ }^{13}$ In addition, rising debt levels lead to rising wealth inequality and a host of associated problems.

${ }^{14}$ Empirical evidence seems to support the proposition that the marginal propensity to consume declines as income increases.
} 
weakness can then undermine the health of the financial system. ${ }^{15}$ In extremis, this can lead to a 1930s type of debt-deflation or even hyperinflation as governments resist such processes through monetary expansion. ${ }^{16}$

Nor is the stability of the financial sector sufficient to ensure stability in the real sector. Reinhart and Rogoff (2009) document many historical cases where the real economy had a steep downturn in spite of the financial sector continuing to function quite well. Koo (2003) also suggests that the Great Recession in Japan was not due to a weakened banking sector, and an inadequate supply of credit, but rather to an inadequate demand for loans as corporations tried to reduce debt after a long period of overexpansion. Similarly, European respondents to the ECB's Access to Finance Survey have since 2015 ranked the availability of credit among the least of their concerns. ${ }^{17}$ The problem appears to be a reluctance to invest against a backdrop of high corporate debt, and thus a decrease in the demand for loans rather than a decline in supply.

A corollary of this insight is that efforts to increase the stability of the financial sector can even increase the likelihood and cost of crisis in the real economy. This could be the result if risks are simply shifted out of the financial sector onto the shoulders of households and corporations that are less well placed to bear them. The replacement of defined benefit pension plans with defined contributions is a case in point. Securitization of risky loans is another. The unfortunate implications of securitizing mortgages (Collateralized Debt Obligations) prior to 2007 are now obvious, though the implications of more recent attempts to securitize corporate loans (Collateralized Loan Obligations) remain to be seen. Finally, Mian (2019) suggests that concern about the health of the financial sector has been an important impediment to introducing statecontingent risk sharing, even though it might help to soften the slowdown of household spending in downturns.

Accepting the reality and importance of the financial cycle implies the need to reject a number of the hypotheses that were central to the belief system prior to the crisis. Financial markets might well be "efficient" in evaluating relative risks and returns at a moment in time. However, if they systematically alternate between unwarranted bouts of optimism and pessimism ${ }^{18}$ over time, then they are clearly inefficient in some broader sense. Large misallocations of capital seem not only possible but likely. As well, innovation in the financial sphere is not necessarily welfare enhancing but could be motivated by rent seeking or regulatory arbitrage. ${ }^{19}$

Beliefs about how the real economy functions also have to change. Since the busts following booms are long and deep, ${ }^{20}$ a basic assumption underlying widely used economic models (real business cycle models and DSGE models) is violated. Economies do not have properties that

\footnotetext{
${ }^{15}$ Consider Reinhart and Rogoff (2009) p. 145, who state "Severe financial crises rarely occur in isolation. Rather than being the trigger of recession, they are more often an amplification mechanism." For a modern example, think of developments in the Italian banking system induced by an essentially stagnant Italian economy.

${ }^{16}$ Sargent and Wallace (1981) provide a theoretical explanation for such an inflationary outcome. Bernholz (2006) provides many historical examples to support the theory. See also Bordo and Meissner (2016).

${ }^{17}$ See the discussion in Finance Watch (2018) pp 12-13.

${ }^{18}$ Essentially the ebb and flow of "animal spirits" described by Keynes (1961).

${ }^{19}$ Recall Chairman Volcker's famous comment about financial innovation and ATM machines.

${ }^{20}$ Reinhart and Reinhart (2010).
} 
quickly restore "equilibrium" when production falls below pre-crisis trends. Had the IMF and OECD, among others, accepted this fact, they might have avoided an embarrassing outcome. Each organization had to revise downward its next-year forecast for global growth for nine consecutive years after the onset of the crisis. $^{21}$

It is also important to note that monetary policy has become ever more ineffective in stimulating aggregate demand as it has been used asymmetrically over repeated cycles. With positive, global supply side shocks holding down prices, it has in fact been possible since the late 1980s to ease policy more aggressively in downturns than to tighten it in upturns. This has implied that the "headwinds" of debt, and the other unintended consequences of monetary easing, have not been extinguished in each cycle. Rather, they have been allowed to accumulate over time. This perhaps helps explain why the response of aggregate demand to monetary stimulus was greater in 1990 and 2000 than it was subsequent to 2009.

As an illustration of these cumulating effects, the global ratio of non-financial debt to GDP was significantly higher in 2019 than it was in $2008 .^{22}$ The growth of private sector debt was particularly marked. Moreover, whereas rising private sector debt was previously an advanced economies phenomenon, by 2019 it had affected many emerging markets as well. Whereas public sector debt ratios have risen most sharply in advanced countries, governments in many of the world's poorest countries had record high debt ratios even prior to the pandemic.

The effects of monetary stimulus are not limited to its intended effects on aggregate demand. There are many other unintended consequences as well. Critics at the OECD and the BIS have repeatedly suggested that easy monetary conditions can also reduce aggregate supply by encouraging resource misallocations in upturns and by providing support for zombie companies ${ }^{23}$ and zombie banks in downturns. ${ }^{24}$ The proportion of zombies among listed companies has risen sharply since the turn of the century and this development has been increasingly linked to declining rates of growth of total factor productivity. These concerns have been exacerbated by the fiscal and monetary backstops provided to the corporate sector since the onset of the covid-19 pandemic. The need for a rapid policy response meant that less time was available to distinguish between appropriate and inappropriate recipients. ${ }^{25}$

Finally, monetary stimulus can have the unintended consequence of actually increasing financial instability. ${ }^{26}$ Low intermediation margins and the search for yield foster the instability of financial institutions. As in the advanced countries, lending by "shadow banks" in both China and India is increasingly viewed as a potential cause of future financial instability. Market prices, under the influence of central bank policies, can increasingly deviate from fundamentals (also

\footnotetext{
${ }^{21}$ This was due in part to the failure to recognize how the level of potential had weakened due to earlier weak investment.

${ }^{22}$ See the non-financial debt statistics (households plus corporates plus governments) compiled by the Bank for International Settlements. Also, Buttiglione et al. (2014).

${ }^{23}$ A common definition is a company that is over ten years old and has had interest coverage of less than one for three consecutive years.

${ }^{24}$ See Borio et al (2015), Andrews et al. (2017) and Banerjee and Hoffman (2018).

${ }^{25}$ Lynch D. J. (2020).

${ }^{26}$ White (2016).
} 
increasing the chances of resource misallocation) and market functioning can be impeded. In short, repeated and asymmetric reliance on monetary stimulus has made the work of both future central bankers and financial regulators ever more challenging and perhaps, in the limit, impossible.

\section{The Case for Adopting a Macrofinancial Stabilization Framework}

The above arguments all indicate that it would have been better to "lean" against excessive credit growth in successive upturns than to try to "clean up" afterwards. How might this have been done, and how might it conceivably be done in the future? A longstanding suggestion has been the need to adopt a macro-financial stabilisation framework; ${ }^{27}$ namely, the joint use of monetary tightening and more restrictive macroprudential regulation to resist credit developments judged likely to turn into a "boom-bust" cycle. Support for this approach, directed to the pursuit of financial stability, has been expressed by Stein (2003), Tucker (2014) and the Committee on International Economic Policy and Reform (2011).

At a more formal level, this framework seems suggested by literature discussing the governance of other, complex adaptive systems. ${ }^{28}$ A variety of negative feedback rules are commonly required to stabilize such systems. Unfortunately, policy efforts to ensure stability in our economic and financial systems have all been premised on the invalid assumption that those systems are not only separable but also understandable and easily controllable, like a machine. It is this assumption that has fundamentally underpinned the separation of monetary and regulatory policies and the policy choices made to date. Fortunately, there are many other complex, adaptive systems in nature and society whose properties have been studied by many other disciplines. Their insights should also help guide economic policymakers. ${ }^{29}$ In effect, we need a paradigm shift in how we think about the nature of the economic system we are trying to control. ${ }^{30}$

At a less formal level, the macrofinancial stability framework was initially thought of as a "belt and braces" approach to the fact that each set of instruments had both advantages and disadvantages. Monetary tightening was desirable since, as Stein (2013) famously said, "monetary policy gets in all of the cracks." However, relying solely on monetary tightening might result in destructively high interest rates for the whole economy, when the credit problem was actually quite localized. As for macroprudential tightening, such instruments could be fine tuned to deal with localized events. In contrast, the downside of such measures included being prone to evasion by highly adaptive agents, not least by diverting credit origination to less heavily regulated sectors. These issues are discussed further below.

\footnotetext{
${ }^{27}$ See White (2005), White (2009) and Borio (2014). For a recent paper which adds to an impressive body of BIS research in this area, see Borio et al. (2018).

${ }^{28}$ For a very early discussion see Meadows (1997) and for more specific references to complex, adaptive economic systems see Kirman (2010).

${ }^{29}$ For a recent effort to draw some lessons for central banks, see White (2017). For broader reflections on how complexity affects the financial system see OECD (2020).

${ }^{30}$ The OECD, through its NAEC (New Approaches to Economic Challenges) project has been spearheading such thinking for almost a decade. It has pursued a highly interdisciplinary approach in association with INET Oxford and the International Institute of Applied Systems Analysis among others. For an early review of this work, see OECD (2015) and, for a more recent one, OECD (2020).
} 
The central banking community has essentially rejected the idea of using monetary policy to lean against credit excesses. The most important reason cited is that this approach might at times mean undershooting their near-term inflation target, which central bankers remain remarkably loath to do. ${ }^{31}$ Another reason, held in spite of accumulating evidence to the contrary, is what seems to be a lingering belief in the Greenspan doctrine that it is easy to clean up after a credit bust. Third, it might also be the case that ever-accumulating debt levels, over the last few decades, have alerted central bankers to the dangers of monetary tightening for whatever reason. ${ }^{32}$ However, this last consideration leaves open the possibility that, in a future world where the debt problem has been resolved, there might be a greater willingness to revisit this issue.

A final reason for doubting the efficacy of "leaning" is said to be the practical difficulty of actually deciding when to lean. It is not at all clear that these are inherently any greater than the difficulties faced by current policymakers pursuing the objective of price stability. ${ }^{33}$ Moreover, these difficulties might have been overestimated. At the moment, there appear to be two schools of thought about which indicators to look at when seeking to pre-empt future crises. One school, which is the more promising, focuses on highly aggregated data, like credit growth relative to trends and exaggerated prices for financial assets (including property). ${ }^{34}$ These have been recurrent features of financial crises in the past. A wide variety of such indicators should be compiled to inform monetary policy decisions about underlying credit conditions. ${ }^{35}$ Relying on single indicators, like stock prices, risks the accusation that monetary policy is trying to "prick bubbles" which should not be the objective of policy.

Attention has been diverted from these aggregate indicators by a second school of thought focused on highly disaggregated financial data, so called Risk Maps. These reveal more about nodes of pressure and possible rupture points within the financial sector, than they do about broader problems arising from aggregate credit growth. This second approach has received strong support from the $\mathrm{G} 20^{36}$ although it is inherently much more resource intensive. Moreover, complexity theory clearly advises that identifying "triggers" for crises is much less likely to be successful than identifying underlying tensions. That said, there are historical

\footnotetext{
${ }^{31}$ In recent years, decimal point undershooting of inflation targets has elicited unprecedented policy responses. This is surprising since there is little historical evidence that very low inflation or price declines cause economic depression. Indeed, historically, most such periods have been associated with rapid productivity growth and strong increases in overall demand spurred by lower prices. See Atkeson and Kehoe (2004).

${ }^{32}$ See the discussion of this, so-called "debt trap" issue in the report by the Group of Thirty (2015). The "debt trap" refers to a situation where rates cannot be lowered further, since this will exacerbate existing debt problems, but they also cannot be raised because this could trigger the very crisis the authorities are trying to avoid.

${ }^{33}$ For example, the current policy reaction function demands knowledge of the natural interest rate and the natural rate of unemployment, both of which are unobservable and must be inferred from other data.

${ }^{34}$ A seminal reference is Borio and Lowe (2002).

${ }^{35}$ Kohn (2020) describes the process of stress testing at the Bank of England and how the results can inform decisions about using countercyclical capital buffers. The IMF and OECD have both made efforts to quantify changes in financial conditions, associated changes in financial vulnerabilities, and the subsequent effects on economic growth. See Adrian et al. (2019).

${ }^{36}$ Of the 20 data areas highlighted by the Financial Stability Board (2009) as requiring significant improvements, 17 had to do with the financial sector. The "main data gaps (are) those related to financial interconnectedness.... and the build up of risk in the financial sector."
} 
grounds for beliefs that crises are often triggered by developments in specific markets (for example, junk bonds) that are either new or have been subject to very rapid growth. ${ }^{37}$

As for the use of macroprudential regulations to lean against credit bubbles, a number of advanced market economies have turned to their use in recent years. However, it is crucial to note that this has not generally been done in support of tighter monetary policy directed to the same objective. Rather, in sharp contrast to the recommendation above, they have been tightened to avoid some of the undesired side effects of "lower for longer" monetary policy. ${ }^{38}$ Monetary and macroprudential policies are thus being treated as offsets to each other (substitutes) rather than complements. Since it has been argued above that the repeated use of monetary easing renders it less effective, and that the undesired side effects cumulate over time, the adoption of this combination of policies needs far stronger analytical support than has thus far been provided.

It should be noted, for completeness sake, that changes in microprudential regulations have inadvertently had procyclical effects for a very long time. ${ }^{39}$ Regulations were tightened during the Great Depression and then systematically eased in the decades of strong growth leading up to the crisis of 2008. Since that crisis, they have again been systematically tightened, running the risk of conflict with an aggressively expansionary monetary policy. ${ }^{40}$ True to form, as the major economies crawled back towards full employment in the years prior to the pandemic crisis, new initiatives were taken to roll back the earlier moves towards tightening. ${ }^{41}$ Since the pandemic began, the pressure for rollbacks or forbearance has greatly increased. ${ }^{42}$

Most of the pre-pandemic pressure for regulatory easing arose from the financial industry itself. ${ }^{43}$ However, supervisors might have opened the door somewhat by suggesting, albeit totally reasonably, that "It is a good time to take a step back and ask how the different bits and pieces of the regulatory framework fit together." institutions forcefully argued that a regulatory rollback, at such a late stage of the business and financial cycle, would have been highly imprudent. ${ }^{45}$ In contrast, since the pandemic began,

\footnotetext{
${ }^{37}$ The Economist (2014).

${ }^{38}$ Woodford (2015).

${ }^{39}$ Dagher (2018).

${ }^{40}$ A counter argument says that the demand for credit collapses in a bust. Thus no short-term harm is done by tightening microprudential standards and making the system safer over time.

${ }^{41}$ See Antilla (2018) as well as Masters (2019). In the US the emphasis has been on rolling back the Volcker rule and lightening the regulatory burden on smaller banks.

${ }^{42}$ For one of many examples, see Isaac and Vartanian (2020).

43 Arguments used include the assertion that regulations are cutting credit growth and demand in turn, that compliance is expensive and complicated, and that supervisors have been given "excessive" powers.

${ }^{44}$ Quoted in Kulati and Hartwell (2017).

45 Among them would be Jaime Caruana, Sheila Bair, Janet Yellen, the IMF, OECD and the Systemic Risk Council in the US. On a particular issue, the proposed rollback of the authority of the US FOSC to designate non-bank financial institutions as being systemically important, a letter sent to Secretary Mnuchin (Treasury Department) and Chairman Powell (Federal Reserve) was jointly signed by two previous heads of the FOSC and the two previous heads of the Federal Reserve. It vigorously opposed the rollback. While the rollback proceeded, regardless, the FOSC conceded that it would introduce an "activities-based approach" to non-bank financial companies.
} 
there does seem to have been a greater willingness to exercise regulatory forbearance, at least with respect to enforcing newly issued regulations. ${ }^{46}$

\section{Shortcomings in the Use of Time-Varying Macroprudential Policies}

Posit a phase of economic expansion with monetary policy narrowly directed to the objective of price stability. In addition, posit a rapid rate of credit growth that might culminate in a costly "bust." Could time varying macroprudential policies, used in isolation, suffice to ward off that danger? Basel 3, ${ }^{47}$ promulgated in 2010, includes the possibility of a Counter Cyclical Capital buffer that could be raised to a level as high as 2.5 percent of risk-weighted assets. In addition, Cerutti et al (2018) record a large number of macroprudential instruments (like loan to value ratios, reserve requirements and lending limits of various sorts) that could also be varied, by national authorities, in pursuit of that objective.

Before turning to the question of the effectiveness of such a policy, a crucial shortcoming noted above must be underlined. Those currently charged with macroprudential regulation do not have the objective of leaning against the financial cycle. Barwell (2013) documents how post-crisis regulators in the UK and in Europe began with this objective, but then slowly retreated into a much narrower one. In the US, a narrower objective might have been the case from the start. All these regulators are now focused on preserving the stability of the financial system, defined as a system capable of providing essential services even in the aftermath of a financial crisis. As with monetary policy, macroprudential policies have become more focused on resilience (clean up after) than sustainability (lean against the unsustainable).

Why this narrowed focus? In part, it might have been due to a sense that the broader objective was simply unrealistic. Experience with the use of time varying macroprudential instruments in Spain (dynamic provisioning) and in Hong Kong ${ }^{48}$ to lean against credit booms, did not avert a serious subsequent crisis. ${ }^{49}$ However, it did leave the banks significantly healthier than otherwise. Moreover, macroprudential regulators must have retained serious doubts about whether they could actually deliver even the narrower objective of financial stability. Indeed, closer examination does indicate formidable, practical impediments to achieving that goal.

Doubts about the effectiveness of time-varying macroprudential measures, to pursue stability within the financial system, begin by recognizing shortcomings in the regulatory governance structure at the international level. ${ }^{50}$ The establishment of the G20 in 2008, along with the "upgrading" of the Financial Stability Forum to the Financial Stability Board, gave greater

\footnotetext{
${ }^{46}$ See Isaac and Vartanian (2020). Veron (2020) documents how the Federal Reserve announcement of April 1 (regulations concerning the supplementary liquidity ratio) and the Congressional legislation of March 27 (allowing banks to ignore current expected credit loss provisions) have both eased US regulatory constraints in the postpandemic period. The Basel Committee also agreed to delay, by a year, implementation of the final pieces of Basel 3.

${ }^{47}$ See Basel Committee on Banking Supervision (2010a) and (2010b).

${ }^{48}$ Leung (2015).

${ }^{49}$ It is noteworthy that, because of their exchange rate regimes, neither Spain nor Hong Kong could conduct an independent monetary policy. Thus, the question of whether the joint use of monetary and macroprudential instruments might have been successful could not be tested.

${ }^{50}$ These shortcomings have implications for both macroprudential and microprudential regulation.
} 
political legitimacy to international regulatory bodies. So too did the expansion of the membership of many existing groups to all G20 members. ${ }^{51}$ Yet there was a quick retreat from early suggestions that internationally agreed financial regulations might be enshrined in international hard law (treaties) and enforced by a designated international financial institution. ${ }^{52}$

Rather, the international process continues as before, a patchwork of soft law standards, principles, recommendations and codes of conduct. International discipline now consists of oversight by relevant bodies, ${ }^{53}$ Financial Stability Assessment Programs by the IMF (as before), and peer pressure to support compliance. The concern raised by this diverse oversight structure is that compliance might easily "crack at the first sign of trouble.",54

At the national (and European) level, many new bodies were set up to focus on the pursuit of financial stability. This was a major step forward. Nevertheless, most of these bodies are inter agency committees, implying that diverse agency objectives and the inevitable turf battles will impede the promulgation of clear recommendations. ${ }^{55}$ Moreover, with very few exceptions, these oversight bodies have no powers of compulsion. ${ }^{56}$ At best, a few have provisions to "explain or comply." When one considers the inherent difficulty of making judgements about when to act, in the interests of ensuring financial stability, these national arrangements seem a blueprint for inaction. $^{57}$

The difficulties involved in knowing when to act are indeed formidable. ${ }^{58}$ The first issue is specifying clearly the target we are trying to achieve. If the objective is ensuring the provision of essential financial services in difficult circumstances, what are those services and what level of provision would be adequate? A second issue involves the assessment of tradeoffs.

Macroprudential tightening will have real economic costs in growth forgone. Are the costs worth it, compared to the estimated costs of the crisis that the tightening is trying to avoid? ${ }^{59}$ Answering this question will also demand an assessment of the adequacy of insolvency procedures for financial firms, since spillover costs from single bankruptcies could constitute a large part of the overall costs of financial instability.

\footnotetext{
51 The Basel Committee on Banking Supervision and the other BIS based committees all saw their memberships grow towards the inclusion of all the G20 member countries.

${ }_{52}$ See for example, Eatwell and Taylor (2000).

${ }^{53}$ For example, the BCBS regularly reviews whether countries are meeting the requirements set by Basel 3.

${ }^{54}$ Finance Watch (2018) p30. Also, Veron (2020) who notes how a new Fed rule breaches the Basel 3 Accord.

${ }^{55}$ Goodhart and Schoenmaker (2019), referring specifically to the activation of countercyclical capital requirements, state that "the political economy of capital requirements may lead to a biased approach."

${ }^{56}$ Edge and Liang (2019).

${ }^{57}$ Berner (2018, p. 5) states "I am also concerned that the Financial Stability Oversight Council (FSOC) is walking back from its mission to identify and mitigate threats to financial stability and promote market discipline." Since Berner was the previous head of the Office of Financial Research (OFR) at the US Treasury, his views should carry considerable weight. Feldberg (2018), another previous employee at the OFR, identifies shortcomings in data sharing and an unwillingness of the FSOC to pursue issues that might discomfort one or other of its member agencies.

${ }^{58}$ For an excellent discussion of the issue of how to use time-varying macroprudential instruments in practice, see Barwell (2013).

${ }^{59}$ We are far from having an answer to this broad question. More narrowly, Cerutti et al (2016) conclude "the empirical evidence on the effectiveness of macroprudential policies in influencing credit flows and asset prices is, however, still preliminary and sometimes inconclusive."
} 
The next difficult task is identifying when systemic risks have risen enough to warrant action. One important issue is that we have no agreed model of the interlinkages that affect how financial crises unfold, ${ }^{60}$ and thus no way of calculating the probability of a financial crisis. It may in fact be impossible to agree on such models since financial systems are complex, adaptive systems likely to have multiple equilibria and highly non-linear outcomes. A further complication, emphasized by Scott (2016), is that crises may have their roots not in interconnectedness but rather in contagious panic. Predicting such a shift in sentiment would seem even more difficult.

Once the need to act has been decided, what precisely to do is another difficult issue. In principle, the list of possible instruments is long; a cap on loan to value or loan to income ratios, balance sheet restrictions on lenders, countercyclical capital or reserve ratios and a host of other instruments. But in practice, as in the US currently, some of these instruments might not be legally available. ${ }^{61}$

A further complication is that many macroprudential instruments, for example countercyclical capital requirements, are actually microprudential instruments being used for a different purpose; systemic stability rather than institutional stability. This last complication raises two questions. Is the instrument legally available for use by the macroprudential authority? If it is, will the microprudential authority take offsetting action to achieve its particular objectives? Further, in some countries (like the US), regulatory changes made at one level of government might be met with offsetting changes at some other level of government. These possibilities add another layer of complexity to the adaptive changes likely to be made by the market itself to whatever changes are made to the regulations.

The decision to use any individual instrument should depend on a careful assessment of its effects on growth as well as on financial stability. Unfortunately, those charged with responsibility for macroprudential regulation will generally have only a limited understanding of either effect. Moreover, it is a political reality that the distributional effects of the use of different instruments must also be considered. For example, in recent years the lowering of loan to value ratios for mortgages in some countries has been criticized for its effects on the ability of poorer households to buy a house. When policy makers start to consider packages of instruments, with interacting effects on all three objectives (the stability of the financial sector, economic growth and distribution), the uncertainty about the effectiveness of policy rises commensurately.

Finally, even if we know "what" to do, a number of "how" questions remain. Should macroprudential policies prohibit certain financial activities outright, or change the incentives to pursue them? Should policy changes be based on rules or discretion or some combination of the two? Should policy changes be incremental or are large changes required to change mindsets and

\footnotetext{
${ }^{60}$ Which is not to say that no progress has been made. See Mester (2015) on the role played by research in informing the process of financial regulation in the post-crisis period.

${ }^{61}$ The Federal Reserve is limited to changes in margin requirements on equity purchases, unchanged since 1974 , and changes in the countercyclical capital requirement. See Buiter (2018).
} 
expectations about the future? ${ }^{62}$ The answer to each question will rest on universal analytical insights, but also on the idiosyncratic characteristics of each regulatory domain.

All the arguments above indicate that the use of time-varying macroprudential policies, even in pursuit of the limited objective of stability within the financial sector, will prove very difficult. This perhaps explains why so much effort, in the post-crisis period, has gone into other (nontime varying) policies designed to improve the chances of financial stability at all stages of the cycle. Some of these policies focus on systemic stability (and are therefore still defined as macroprudential), but most focus on individual institutions or markets (and are defined as microprudential).

\section{Shortcomings in the Use of Non Time-Varying Macroprudential Policies}

Certain structural characteristics of the financial system could have implications for the stability of the financial sector as a whole. Regulatory attention has focused on identifying Global Systematically Important Banks (GISBs) and how they might be wound down without unacceptable side effects and with minimal costs to taxpayers. Significant attention has also been put on reducing interdependencies in the financial system that could lead to systemic distress. While important progress has been made significant shortcomings still need to be addressed, as do the problems of unintended consequences arising from the policies adopted.

Thirty global institutions have been designated as Global Systemically Important Banks by the Financial Stability Board. It is an important advance that this designation reflects a variety of objective criteria including size, complexity, interdependence and a dominant influence over an important part of the financial system. Firms designated as G-SIBs simply cannot be allowed to fail in a disorderly way because the collateral damage to the system (the Expected Losses) would be too great.

However, receiving this designation is almost an invitation to lenders to G-SIBs to lend on inappropriately easy terms. A G-SIB designation must then go hand in hand with improved resolution procedures to ensure that lenders to G-SIBs would still face significant losses in the event that the firm needed to be restructured. Replacing "bail-out" with "bail-in" would also reduce moral hazard and change significantly how the firms were managed.

Broadly speaking, the attempted solution to this problem has been to recognize that Expected Losses, for the economic system as a whole, are defined as being the product of two terms; the Probability-of-Default (PD) and the Losses-Given-Default (LGD). ${ }^{63}$ Policy efforts have been directed at reducing both terms.

\footnotetext{
${ }^{62}$ Kohn (2020) notes that future threats to the stability of the financial system become clear only quite late in the financial cycle. To increase capital requirements by the amount required to safeguard the system in the subsequent downturn would then demand a rate of increase that would likely be politically impossible.

${ }^{63}$ LGD include both explicit balance sheets losses and the implicit losses caused by collateral damage to the economy. While the authorities wish to lower LGD overall, they wish to raise the proportion of the balance sheet losses absorbed by the private sector. This raises the complex question of the intertemporal trade-off between better crisis management (safety nets which reduce losses today) and moral hazard (which raises losses tomorrow).
} 
The Probability-of-Default has certainly been reduced by the microprudential measures (discussed below) that apply to all banks. In addition, there has been a special capital surcharge imposed on G-SIBs ${ }^{64}$ as well as other measures to ensure private sector lenders, rather than taxpayers, bear the burden of prospective losses. Of particular importance has been the requirement that G-SIBs issue long term debt that can be converted into equity in the case of resolution. The Total Loss Absorbing Capacity (TLAC) of these institutions was raised to 16 percent of risk weighted assets in 2019 and will rise to 18 percent in 2022. Tarullo (2016) also emphasizes, for US based banks, significant improvements in data availability and risk management procedures more generally. Finally, Yellen (2019) describes the more stringent application of stress tests to the largest US banks as "the most important supervisory innovation since the financial crisis."

These are significant regulatory improvements. Nevertheless, a number of concerns remain. Not all supervisory decisions have gone unquestioned. For example, was it prudent for US supervisors to have allowed (on average from 2017 to 2019) the largest six US banks to pay out to shareholders significantly more than 100 percent of profits? As for the TLAC provisions, Goodhart (2017) remains concerned that triggering private sector losses of large magnitude, in the case of resolution, would be (p2) "likely to lead to a widespread collapse of the bank bond market as a whole, at least for a time, with implications for contagion." Benink (2020) gives other reasons for doubting the "credibility" of the TLAC numbers. As for improved stress tests, Kohn (2020) refers to some of their remaining and significant limitations. ${ }^{65}$

Another concern focuses on the market's assessment (using share prices and other inputs) of the likelihood of default of banks affected by new capital regulations. Sarin and Summers (2016) conclude that they "find no evidence that markets regard (big) banks as safer today than they were before the crisis." In effect, they contend that the effects of higher capital requirements have been offset by reductions in franchise value arising from other regulatory changes. Acharya (2010) and Blundell-Wignall (2013) use market generated data to draw similar conclusions, with the latter emphasizing the exposure of large banks to potential losses from trading in derivatives.

It is also instructive to remember that Lehman Brothers was judged to be well capitalized the day before it went bankrupt in September 2008. Similarly, stress tests of banks in Europe have regularly been easily passed by banks that shortly afterwards required significant government support. The much diminished status of a number of European G-SIBs, relative to their American counterparts, raises another source of concern about their longer time viability. Recent comments about Japanese monetary policy by the Chairman of Mizuho (one of three Japanese

\footnotetext{
${ }^{64}$ Tarullo (2016) p. 9, asserts that the bank surcharge in the US reduces the Expected Loss to a level approximating that of a large bank holding company that has not been designated as a G-SIB. Buiter (2018) p. 7, is less comforting when he asserts that "systematically important non-bank financial intermediaries remain woefully undercapitalized and have increased their share of total financial intermediation as a result of regulatory arbitrage."

${ }^{65}$ Not least, stress tests are conducted on a "bank by bank basis with no explicit accounting for the effects of correlated positions or interconnections."
} 
mega banks), is a pertinent indicator from an industry insider that even large firms remain vulnerable to the unintended consequences of monetary policy. ${ }^{66}$

Reducing the collateral damage due to the bankruptcy of a G-SIB (Loss-Given-Default) could be done in a variety of ways, but each has proved hard to implement. Many have called for such institutions to be carved up into smaller ones. There has been little appetite for this, perhaps because a larger number of similarly structured and managed firms might be as much a source of systemic instability as one big firm. ${ }^{67}$

Indeed, it is notable that, in some countries, particularly the United States, the individual size and relative importance of the largest banks within the banking sector has actually grown significantly since the crisis. Ironically, this has been due to officially sanctioned mergers and acquisitions. In early 2019 serious consideration was also given to the possibility of a merger between the two largest private banks in Germany, indicating that this trend to consolidation might well continue. Further, there have been repeated calls in Europe for cross border bank mergers to produce banks big enough to compete internationally with much larger US banks. Evidently, this dynamic is not going in the right direction.

Calls have also been heard for firms to be split along functional lines, ${ }^{68}$ though only in the UK have such proposals (following the Vickers Report) been implemented. The underlying assumption that investment banking is much riskier than retail banking has by no means been generally accepted. ${ }^{69}$ Attempts have also been made to reduce the interdependencies among GSIBs, not least through the Volcker rule which targeted proprietary trading because it was predominantly done with other G-SIBs. ${ }^{70}$ Littan (2011) describes the politics and practicalities militating against enforcement of the Volcker rule, while Antilla (2018) notes successive rollbacks to date.

Great efforts have also gone into improving resolution procedures for G-SIBs, with the Financial Stability Board publishing a key document on this in $2011 .^{71}$ The new philosophy suggested was that national regimes should seek to preserve critical functions. Emphasis should be put therefore on the effective resolution of groups supporting such functions rather than legal entities only.

\footnotetext{
${ }^{66}$ Ultra easy monetary policy in Japan, as elsewhere, has squeezed profit margins and forced a re-evaluation of previous business models. Japanese banks have increased risky investments abroad and have just begun to cut rural branches in a serious way. See Jenkins (2019), where the title says it all 'Not just a Japanese disease: Mizuho's woes afflict the world."

${ }^{67}$ Goodhart (2013), p. 255. Also Borio et al (2020) who state (p. 44) "Basel 3 does not recognize explicitly that, as a group, even small banks can generate systemic risk." The paper then makes reference to the "small banks" crisis in the UK in the early 1990s and the "caja" crisis in Spain in 2010.

${ }^{68}$ Many commentators in the US advocate bringing back the Glass Steagall Act. Also consider the Liikanen proposals in Europe.

${ }^{69}$ See Goodhart (2013) and Buiter (2018).

70 Paul Volcker has stated that the Volcker rule was not directed to reducing proprietary trading as such, since such trading was not an important contributor to the crisis. Rather, the objective was to reduce the interdependencies between large firms. Volcker felt that these interdependencies increased uncertainty among regulators about the effects of closing any one of them down. This uncertainty encouraged the government bailouts which occurred in the US in 2008.

${ }^{71}$ FSB (2011). Also see the provisions in the Dodd Frank Act in the US and the establishment of the Single Resolution Authority in Europe.
} 
One problem is that most G-SIBs have enormously complex internal structures, sometimes with thousands of subsidiaries. Another problem is that they all operate internationally and are therefore subject to both domestic and foreign legislation. Similarly, they are of interest to both home and host supervisors. This requires cooperative solutions for both crisis management and crisis resolution which cannot always be assured. ${ }^{72}$

There are in fact a number of constraints impeding the degree of international cooperation likely to be required to resolve a G-SIB in an orderly way. First, individual countries will be loath to cede the degree of sovereignty likely to be necessary for an ideal resolution procedure. Second, countries will be tempted to ring fence the assets held in their jurisdiction. Third, differences in national practices might impede international cooperation. ${ }^{73}$

One attempt to deal with the complexity issue has been to force G-SIBs to construct a "Living Will," effectively a roadmap as to how the firm might be broken up and parts wound down in an orderly way. Supervisors must be satisfied with the feasibility of such plans and can reject them. ${ }^{74}$ However, in many jurisdictions, they lack the legal power to force a reorganization more to their liking. Another development, raising the likelihood of an orderly resolution of a G-SIB, has been the requirement that they issue debt that can be reliably "bailed-in" to pay for losses in the case of bankruptcy. Presumably, the resolution authorities will find it easier to act knowing that taxpayers will not be liable for their actions. ${ }^{75}$

In spite of these and other important advances, Domanski (2018) notes that "the success of our efforts in the area of resolution will depend on proper implementation" and in this regard "significant implementation work remains, both in the EU and beyond." Similar concerns have been raised by other respected experts. ${ }^{76}$ Each has expressed doubts that it would be possible to resolve a G-SIB today without suffering unacceptable side effects. ${ }^{77}$

Another set of macroprudential policies has been directed to reducing interdependencies in the financial system. In addition to the Volcker rule initiative, noted above, the most important initiatives have been to reduce interbank exposures (especially cross-border interbank exposures) and measures to force derivative trades into clearing houses. Each has a sensible rationale but also some significant downsides.

The essential collapse of the interbank market in 2008 could have led to a whole series of cascading bankruptcies, a process that was avoided only through unprecedented support from central banks. This danger had been flagged by a BIS committee as far back as the early 1980s

\footnotetext{
${ }^{72}$ Borio et al. (2020), Box C discuss important cross border challenges arising in the case of resolution. Both the single point of entry and the multiple point of entry resolution procedures have advantages and disadvantages.

${ }^{73}$ Fernandez de Lis S (2016) p. 26.

${ }^{74}$ Indeed, the Fed has already rejected a number of such proposals. Buiter (2018) p. 11, points to a common problem. "The living wills I have thus far seen don't seem likely to be implementable at the speed with which crises occur."

${ }^{75}$ The key word is "easier" rather than easy. Recent experience in Italy shows the political difficulty of bailing in retail bond holders.

${ }^{76}$ For example, see Duffie (2016), p. 3; Mester (2015) p. 11; Goodhart (2013); and even Janet Yellen (2019).

${ }^{77}$ Tarullo (2016) speaks eloquently of the need to assure orderly resolution but is then silent on what else needs to be done, if anything, to ensure this can happen.
} 
and the issue was returned to repeatedly. ${ }^{78}$ In the end, however, not much was done. The fundamental problem, then as now, is that interbank lending is a key part of an efficient financial system. It transfers money from banks with excess deposits to banks with an excess demand for loans. It also facilitates the temporary financing of current account deficits. The difficult issue is determining the point when this efficiency has become "too much of a good thing," because it has led to an excessive buildup of debt or other exposures.

After the crisis, there was a marked reduction in cross border interbank lending (as a proportion of all cross-border lending), particularly for European and US banks. The downsides of this were seen most clearly in Europe where the withdrawal of banks in the "core" from the "periphery" led to a collapse in lending and major recessions in all the peripheral countries concerned. Similar developments occurred in South East Asia in the crisis of 1997. These developments demonstrate the eventual costs of intemperate cross-border lending, but they provide no practical guide as to how to moderate such flows in the first place.

Exposures arising from the bilateral trading of derivatives has also been the focus of attention of those worried about interdependencies in the financial system. The solution proposed by the G20 was to provide capital incentives to move derivative trades to regulated exchanges and central counterparties (CCPs). By reducing bilateral counterparty exposures, overall risk management would be improved and systemic risks reduced. Specific steps were also taken to improve the stability of the CCPs themselves. Various layers ("default waterfalls") of loss absorbing capital were required to ensure the CPP would always be able to continue functioning as a "going concern." CCPs were also encouraged to adjust collateral haircuts to build up reserves in a countercyclical fashion. An added bonus associated with these changes was thought to be the provision of much more information about the risk exposure of individual institutions.

These changes were successful in one sense. The proportion of interest rate derivative trades cleared through CCPs rose from $20 \%$ in 2010 to $60 \%$ in 2018, while comparable numbers for credit default swaps rose from $10 \%$ to $40 \% .{ }^{79}$ In part, this was due to significant cost savings for participants who benefitted in various ways from pooling, netting and the operational efficiencies of CCPs. The percentage of centrally cleared FX derivatives doubled, but only from 1 percent to 2 percent of the total.

However, as time has passed, the assessment of the systemic benefits of CCPs has become more nuanced. ${ }^{80}$ It has become increasingly recognized that CCPs do not reduce counterparty risk as much as mutualize it, since the main counterparties of the CCPs tend to be a relatively few systemically important banks. This leaves open the question of whether the system as a whole is more robust or not. Moreover, the links between the CCPs and these banks are varied,

\footnotetext{
${ }^{78}$ The initial Holland Committee, a sub-group of the Eurocurrency Standing Committee at the BIS (later renamed the Committee on the Global Financial System), was followed by the Frankel Working Group, the Yoshikuni Working Group and finally the Brockmeijer Working Group. All of these groups prepared reports and recommendations.

${ }^{79}$ See Faruqui et al. (2018).

${ }^{80}$ A number of the world's largest financial firms recently issued a report stating "despite enhancements in the past few years, the firms believe that there remain outstanding issues relating to CCP resilience, recovery and resolution that require further action." See J P Morgan (2019).
} 
(sometimes including ownership) which adds a further complication to these interactions. The upshot is that "the risks of banks and CCPs should be considered jointly, rather than in isolation." ${ }^{81}$ As well, questions have been raised about how clearing houses assess volatility and set "haircuts" in normal times, ${ }^{82}$ and how squabbling counterparties might refuse to support a CCP close to failure. ${ }^{83}$

Taking this broader perspective, it still seems broadly accepted that central clearing does reduce systemic risks, assuming the CCP is well managed. ${ }^{84}$ Nevertheless, Domanski et al (2015) and Faruqui et al (2018) convincingly argue that exogenous shocks might still lead to destabilizing "domino effects" under some circumstances. Moreover, endogenous interactions might also lead to destabilizing feedback loops. Both studies welcome the increasing attention paid by regulators to such issues, but also warn against complacency given the need for more research into the potential behavior of these complex systems. ${ }^{85}$ Since clearing houses now centrally clear derivatives with a notional value of over 400 trillion dollars, this is not a trifling affair. ${ }^{86}$

There is a final downside to all these macroprudential measures to ensure the stability of the financial sector. To the extent it is thought this stability is now assured, it seems to follow logically that there is no need to develop procedures to better manage future crises. The DoddFrank Act in the United States has a number of provisions ${ }^{87}$ which Yellen (2019) asserts have "scaled back the Fed's emergency liquidity powers, leaving it with a toolkit that could prove inadequate to cope with a situation like the Crash of 2008."88 Given the remaining shortcomings of resolution procedures in the United States, noted above, Buiter $(2018$, p.12) concludes that these new restrictions on the Fed "represents a major error of judgement."

A closely related issue is who might provide liquidity support to non-US firms that might find themselves short of dollars in a crisis. When mainly European banks found themselves in that position in 2008, the Fed lent them almost one trillion dollars, via the US discount window and via FX swaps between central banks. Today, similar exposures to dollar shortages exist, ${ }^{89}$ though increasingly with counterparties from emerging market countries. Moreover, a larger

\footnotetext{
${ }^{81}$ Faruqui et al. (2018).

${ }^{82}$ Stafford (2019).

${ }^{83}$ Dizard (2019). Also see Beau (2019) for recent European efforts to improve CCP resolution procedures.

${ }^{84}$ Unfortunately, this cannot simply be assumed. It demands adequate identification of the risks involved in trades, proper pricing of risk, adequate capital and well-defined procedures for allocating losses. Moreover, a fundamental problem is that "for profit" clearing houses now dominate the industry and they are always tempted to cut standards to increase their market share.

${ }^{85}$ Duffie (2018) p. 3 is still more critical. He contends that most CCPs have become "too big to fail" and that "Effective operating plans and procedures for the failure resolution of CCPs have yet to be proposed." Finally, he notes that "Data repositories for the swaps market have not come close to meeting their intended purposes."

${ }^{86}$ For a recent call for action, see The Economist (2019) and its reference to a letter sent by Paul Tucker, previously the Deputy Governor of the Bank of England, to Randal Quarles, who is responsible for regulation at the Federal Reserve. Tucker refers to clearing houses as "super-systemic," and potentially "a devastating mechanism for transmitting distress across the financial system." Similarly, Dizard (2015) states "The last set of crisis fixes will make the next Big One even bigger. Ground Zero will be the CCPs."

${ }^{87}$ See Scott (2016) and The Group of Thirty (2018).

${ }^{88}$ Yellen (2019) p. 1. The response of the Federal Reserve to the pandemic crisis indicates these concerns might have been overblown.

${ }^{89}$ The BIS estimates the level of dollar liabilities in 2018, issued by non-US residents, at around \$11 trillion.
} 
proportion of dollar intermediation is now being done through non-bank intermediaries (like insurance companies, pension funds and asset management companies) and through marketbased lending. ${ }^{90}$

In the early days of the COVID-19 crisis, the Federal Reserve reopened previous swap lines with foreign central banks and extended them to a number of emerging market countries. However, a number of countries that are highly exposed (like China and Turkey) have not received such support. The fundamental problem is that the international financial system is dollar based, but the US authorities have no legal obligation to support its smooth functioning. The Federal Reserve's policies are therefore entirely discretionary. ${ }^{91}$ The fact that non-bank borrowers make up a rising share of those with dollar liabilities is a further complication to efforts made by central banks to support the system.

The broad conclusion to be drawn from this part of the paper is that the macroprudential policies introduced post-crisis do not seem sufficiently robust to ensure the stability of the financial system, much less the broader economic system. It remains possible, however, that post-crisis improvements to traditional microprudential policies will prove sufficient to meet this broader objective. However, a careful look indicates it would be unwise to draw this conclusion.

\section{Post-Crisis Microprudential Reforms}

In assessing post-crisis microprudential reforms it is helpful to know whether there was anything conceptually wrong with the pre-crisis regulatory framework. Goodhart (2013) asserts that the need for regulatory oversight must begin with the assumption that banks will act "imprudently" if left to regulate themselves. He therefore concludes that regulators in the pre-crisis period did make a fundamental error by adopting the risk measurement tools developed by the banks themselves. Both Goodhart (2013) and Vickers (2017) contend that the assumption of "normality" in the probability distributions used by banks to assess the probability of losses, is inappropriate for prudential authorities who should be worrying about "fat tail" outturns. ${ }^{92}$ If this was a valid criticism, it remains so since the latest version of the Basel regulations (Basel 3) is essentially "more of the same" regime that existed earlier.

For individual banks, the principal threat to their survival is credit risk. In principle, banks protect themselves in three ways. First, they price loans according to the overall risk they bring to the portfolio. This implies paying attention to the gains from diversification. Second, when perceptions of risk change, lenders make explicit provisions for expected losses. Third, institutions hold capital to meet the challenges posed by unexpected losses. The question is whether any identified pre-crisis deficiencies have been rectified by subsequent regulatory changes.

\footnotetext{
${ }^{90}$ For a recent update see Committee on the Global Financial System (2020).

${ }^{91}$ See Aldasoro et al. (2018) and The Economist (2018). If a non-US institution is short of liquid dollars and has to sell longer term US dollar assets, it might have to do so at "fire sale" prices which could exacerbate problems of economic weakness in the US. If it rather chose to sell domestic assets and then swap them into dollars, this would drive up the dollar and exacerbate the dollar shortage problem elsewhere. These arguments, based essentially on self interest, perhaps help explain why the Federal Reserve chose to extend the swap lines.

${ }^{92}$ As Vickers (2017) puts it "The premise of normal risk conditions is simply the wrong basis for the analysis."
} 
The pricing of risky loans has in fact received relatively little attention from regulators. Indeed, prior to 2008 and again in recent years, the narrowing of credit spreads and the decline in market volatility was generally interpreted as a positive sign for the future stability of the system. Instead, it should have been seen as a potentially dangerous by product of ultra-easy monetary policy. Nor has portfolio diversification been seen as a high priority, even though Basel 3 did introduce prudent limits for large exposures. Both before and since the crisis, in most countries, there has been a steady upward drift in the share of loans backed by property in one form or another. This is not encouraging given that property has so often been at the center of "boombust" credit cycles. ${ }^{93}$ The possible negative effects of the pandemic on the demand for office space adds to these concerns. ${ }^{94}$

A significant change has occurred with respect to the treatment of expected losses. Prior to the crisis, provisions for losses were only allowed when the loss was imminent or had actually occurred. This implied that the provisioning which did occur was both "too little and too late." Moreover, since actual losses tended to materialize only when the economy was already in a downturn, there was the possibility that reductions in bank capital at the same time might cut the supply of loans and thus prove "procyclical". 95 These concerns motivated calls for change by the G20.

In July 2014, the IASB published IFRS9, an international accounting standard that responded to these concerns. As of January $1^{\text {st }}, 2020$, a provision must be made for any assessed increase in credit loss expected over the lifetime of the loan. ${ }^{96}$ An added benefit is that banks have been forced to improve their risk modeling capabilities to support any such assessment. One downside is that some countries, like the United States, do not fully adhere to IASB standards since efforts to promote convergence to international accounting standards have not been fully successful. ${ }^{97}$ Another downside is that expectations of the whole string of future losses might be suddenly revised, concentrating much larger expected losses into the early months of a downturn. This would increase "procyclicality" rather than reduce it. ${ }^{98}$ Indeed, since the onset of the pandemic, regulatory authorities have received many calls for postponement of the implementation of IFRS9 for exactly that reason. ${ }^{99}$

The principal development affecting bank capital was the promulgation in 2010 of Basel 3 by the Basel Committee on Banking Supervision (2010a). It raised significantly the level of minimum capital required, using the more granular "risk weights" introduced under Basel 2, and also

\footnotetext{
93 Turner (2016).

${ }^{94}$ Working from home, via the internet, has proven unexpectedly successful and might become a permanent feature of the work landscape.

${ }^{95}$ Huizinga and Laeven (2019) provide evidence that this has been the case historically, with the "procyclicality" being seen in all OECD countries but most pronounced in Europe.

${ }^{96}$ However, IFSR9 also says that, if credit risk has not increased significantly, allowances should be based on losses expected over the next 12 months only.

${ }^{97}$ See Veron (2020) for a fuller description of how US regulatory standards have adapted to international financial standards.

${ }^{98}$ Abad and Suarez (2019).

99 Adrian and Pazarbasioglu (2020) and Stramaglia (2020) address the issue of how banking regulators should respond.
} 
improved those risk weights in a variety of ways. Even more importantly, it significantly limited the definition of what qualifies as capital by excluding a variety of liabilities that would not actually be loss absorbing in a crisis. In addition to the minimum capital ratio of $8 \%$, Basel 3 introduced the two supplementary capital "buffers" already referred to above; one for G-SIBs (1$2.5 \%)$ and the discretionary countercyclical buffer (0-2.5\%). Finally, the provisions demanded a conservation buffer $(2.5 \%)$ before dividend payments or bonuses could be granted.

In addition, Basel 3 introduced a new leverage ratio that limits the total amount of assets (on an unweighted basis) that can be accumulated against a given amount of capital. This was in part a response to the concern that banks were consciously managing down their capital requirements using their own internal models. It was a fact that the ratio of risk weighted asset to total assets had been declining constantly since the introduction of Basel $1 .{ }^{100}$ However, the introduction of a second capital standard also sparked a debate which is ongoing. Is the second standard redundant? Will the two standards interact in undesirable ways in some circumstances? Or do the two standards complement each other given their respective deficiencies?

What is a fact is that capital, as a proportion of risk weighted assets measured at book value, has essentially tripled under Basel 3. Leverage ratios have fallen sharply as well. Yet it has also been suggested that book capital might be a misleading measure of "the distance to default" because of eventual losses that have not yet been recognized. Using banks' market valuation as an alternative and more forward-looking measure of capital reveals a markedly smaller improvement in post-crisis performance. ${ }^{101}$

Even if capital ratios have risen significantly, it still begs the question of whether they have risen enough. All we know is that Basel 3 requirements are significantly higher than Basel 2, a relative rather than an absolute statement. Yet, the Basel 2 levels have been described by Tucker (2018) as "paper thin" and by Lord Vickers (2017) as "hopelessly lax." Martin Wolf (2010) has also observed that "tripling almost nothing does not give one very much." There has in fact never been a rigorous examination of how much capital banks should hold. Basel 2 aggregate requirements were set to match those of Basel 1, and Basel 1 requirements were simply set to maintain the level of capital that the banks then held. ${ }^{102}$

How much capital should banks hold? If capital is to be held as a buffer against unexpected losses then, by definition, the estimated probabilities of losses on individual balance sheet assets can tell us nothing. Unexpected losses are in the realm of "radical uncertainty" not risk. Perhaps a better way to proceed would be to look at capital ratios held voluntarily by banks before the era of limited liability banking and massive safety nets. These ratios were many times higher than

\footnotetext{
${ }^{100}$ See Blundell-Wignall et al (2009). More recently, other measures have been introduced to deal with this problem. The Basel Committee asked different banks to use their internal models to calculate the riskiness of a hypothetical portfolio. The variance of the resulting estimates was shockingly high. The supervisors responded by restricting in various ways ("output floors") the use of internal models to generate risk weights. See Basel Committee for Banking Supervision (2017).

${ }^{101}$ See Ford (2018). Vickers (2017) also suggests that "it would be a good idea to run and to publish stress tests on the basis of market, as well as accounting measures of capital." As discussed above, this qualification applies to GSIBs as well.

${ }^{102}$ Goodhart (2011).
} 
they are today and there is no evidence that lending and economic growth were materially constrained. ${ }^{103}$

Moreover, risks exist today that are unique to the current age. Operational risks are heightened by the ubiquity of technological platforms, often outdated and blended with other platforms after mergers. Digitalization increases the threat to bank profits from FinTech companies. Cybercrime is another current threat. Tucker (2018) notes that future downturns and credit losses might be more severe if monetary policy is hampered by the Zero Lower Bound constraint on interest rates. As well, there is immense uncertainty about the costs to financial institutions of climate change. ${ }^{104}$ Finally, the COVID-19 crisis seems sure to both sharply raise private sector debt ratios and associated losses. All of these "known unknowns" argue in favor of higher capital standards.

A number of well-respected economists have already suggested that banks be required to build up much higher ratios than is currently the case. Admati and Hellwig (2013) call for a 25 percent ratio on an unweighted basis. Moreover, that sentiment seems to be widely shared. ${ }^{105}$ It is important to add, however, that a good part of this capital would have to be available to be run down in the event of an unexpected shock. That is, it would have to be treated as a "buffer" and not as the minimum required by the bank to "retain the confidence of its customers and counterparties." I06 Indeed, concerns have already been expressed that the much smaller "buffers" stipulated under Basel 3 might become unusable if their reduction led to a strong, negative market reaction.

Other concerns have also been expressed about the current capital requirements for banks. Recent European history (particularly with respect to Greece) teaches us that it is inappropriate to give sovereign debt a risk weight of zero. In addition, it encourages government borrowing and worsens the sovereign-bank nexus (the "doom loop") that poses dangers in Europe in particular. There also remain a wide range of views as to whether supervisors should emphasize weighted or unweighted capital ratios. Accounting conventions can also allow exposures to be moved off-balance sheet, flattering leverage ratios. ${ }^{107}$ Finally, the fact that risk weights assigned

\footnotetext{
${ }^{103}$ Admati and Hellwig (2013) argue this would be expected on the basis of the Modigliani-Miller theorem. In contrast, Jackson and Birchler (2012) suggest that there are many reasons why this theorem does not apply in the real world.

${ }^{104}$ The G20 and the FSB have supported the establishment of the Taskforce on Climate Related Financial Disclosure. Financial institutions must now evaluate prospective losses, due to climate change, on the assets they hold. Losses might arise from actual climate change (say, insurance related losses due to flooding) or losses associated with mitigating global warming (say, stranded fossil fuels) or from legal challenges to companies that have contributed to global warming.

${ }^{105}$ See Benink (2020) for a list of economists calling for higher capital requirements, including Alan Greenspan. Checcetti and Schoenholtz (2019) conducted a small survey of risk management professionals and found they wanted capital levels twice as high as current levels and four times as high as the Basel 3 minimum. Goodhart and Schoenmaker (2019) call for a significant increase in the Capital Conservation buffer as a "rules based" alternative to the "discretionary" use (or non-use) of the Counter Cyclical Capital requirement.

${ }^{106}$ Tarullo (2016).

107 See Borio et al (2020). While FX swaps and repos in foreign currency are similar economically, repos are on the balance sheet while swaps are not. At end June 2019, US dollar debt in the form of FX swaps of non-banks outside the US was around \$18 trillion, significantly large than their on-balance sheet debt denominated in dollars.
} 
using internal models can move "procyclically", a shortcoming aggravated by the use of fair value accounting, is a longstanding problem that has not yet been resolved.

Another feature of the Basel 3 framework is that it recognizes that banks face funding liquidity risk as well as credit risk. ${ }^{108}$ New regulations prescribe the need for an adequate level of shortterm liquid assets (the Liquidity Coverage Ratio) and for relying less on flighty sources of funding (the Net Stable Funding Ratio). In light of the market developments in 2009, these requirements seem eminently sensible. Yet a deeper look also raises some questions. If banks are required to hold a certain level of liquidity, can they still use it to meet liquidity needs? ${ }^{109}$ Are both liquidity rules required or could they be simplified into one? ${ }^{110}$ Benink (2019) also raises questions about unintended interactions between the banks' liquidity requirements and their capital requirements.

A more fundamental question is why runs on banks (both retail and wholesale) occur in the first place. Thakor (2018) argues it is because lenders fear the bank will go insolvent and they will not get their money back. But if this is the case, the answer is to raise capital requirements. Finally, if a bank is solvent, the central bank should always be in a position to lend as the lender of last resort, rendering liquidity requirements otiose.

A topic receiving increasing attention is whether post-crisis changes to financial regulation have somehow raised market liquidity risk; that is the likelihood of long periods when "liquid" assets could not be sold at reasonable prices. ${ }^{111}$ Such a development, reminiscent of post Lehman events, could have systemic implications. While markets generally continued to function well in the positive economic conditions prevailing prior to the pandemic, concerns were still being expressed about how well markets might function in less positive economic conditions. The near collapse of financial markets in the early days of the pandemic showed these concerns were justified. As in 2008, an actual collapse was only averted through resolute central bank intervention.

In recent years, market functioning does seem to have deteriorated. Long periods of low volatility, both actual and expected, became increasingly hard to explain against a backdrop of increasing political and economic uncertainty and market "surprises". 112 Moreover, periods of calm have increasingly been interrupted by violent "flash crashes". While recovery generally took only minutes rather than days or weeks, clusters of large market movements have also become increasingly common. ${ }^{113}$ Moreover, a number of market "anomalies" ${ }^{114}$ have been still

\footnotetext{
${ }^{108}$ Basel Committee on Banking Supervision (2010b).

${ }^{109}$ Goodhart (2013) states "A liquidity requirement is an oxymoron." Buiter (2018) goes even further in referring to "The nonsense of the Basel liquidity requirements."

${ }^{110}$ The Shadow Financial Regulatory Committees of Asia, Australia-New Zealand, Europe, japan, Latin America and the United States (2013) raises specific criticisms of the Liquidity Coverage Ratio and make suggestions for an alternative.

${ }^{111}$ For example, see CGFS (2016).

112 The Economic Policy Uncertainty Index has been on an upward trend since 2010. Citi's Economic Surprise Index has registered disappointing data (relevant to expectations) for an extended period.

${ }^{113}$ Wigglesworth (2019) quotes research work done by JP Morgan. "If one defines a shock as a one day drop that is five standard deviations bigger than the daily average movement over the past month, then there have been five such
} 
longer lasting, raising the question of why normal arbitrage no longer seems to be occurring and whether this is a symptom of some deeper malaise. Direct measures of market liquidity (prepandemic) seemed to indicate little or no deterioration in the market for US Treasuries, although there were clear signs of deteriorating liquidity in the market for corporate bonds. However, in the wake of the pandemic, all markets were affected including the market for US Treasuries.

One reason for suspecting that new regulations have played a role in these developments is that US broker dealers, who were previously "market-makers", have sharply reduced both their leverage levels and the absolute size of their balance sheets. ${ }^{115}$ Their inventories of corporate bonds have been particularly affected. However, as Adrian, Kiff and Shin (2018) argue, there are other reasons than increased regulations that might also help to explain this changed behavior. ${ }^{116}$ Not least, their pre-crisis levels of leverage were simply unsustainable. It is also important to note that these portfolio changes began to occur well before these post-crisis changes in financial regulation.

There are also other non-regulatory factors that might have affected how markets function in the post-crisis world. Not least has been the sharp increase in high-frequency (algorithmic) trading, the increased importance of non-bank investors relying on momentum strategies, and the rapid growth of passive index funds ${ }^{117}$ as well as funds that target volatility. When allied with their generally lower levels of capital, these new participants could help explain "a new market regime of stronger, longer rallies, but more abrupt sudden shocks." ${ }^{118}$ Lower, long term interest rates have also reduced the automatic hedging inherent in traditional portfolios, ${ }^{119}$ raising the need for discretionary hedging.

Yet regulatory and also monetary policies might have contributed in other ways to these postcrisis market developments. Much trading is dependent on the availability of acceptable collateral. However, higher liquidity requirements for banks, regulatory impediments to securities lending, quantitative easing and stricter collateral requirement for CCPs all restrict the supply of good collateral and, perhaps, market liquidity in turn. ${ }^{120}$ More broadly, central bank

violent tumbles since 2016 . We have to go back to the 1940 's to find a three year period with as many abrupt slides."

${ }^{114}$ Perhaps the most striking anomaly is that the Covered Interest Rate Parity condition in foreign exchange markets has been persistently violated in the post-crisis period. Further, declining long bond rates signal recession, yet low credit spreads and high equity prices seem to deny this possibility.

115 Adrian and Kiff (2018). As well, market "anomalies" seem to spike on days when regulatory measures are being assessed and "window-dressing" is common.

116 They include relying more on matching order streams and less on inventory management, the effects of lower expected returns, more expensive funding and the growth of non-bank lending and market-making.

${ }^{117}$ As an aside, the rise of passive funds also raises governance issues. Three extremely large asset management firms in the US could now exercise effective control of virtually every corporation in the US. Could they use this power to restrict competition?

${ }_{118}$ Wigglesworth (2019).

${ }^{119}$ A traditional benchmark portfolio would have 60 per cent equities and 40 percent longer term bonds. The logic was that as the economy slowed and equity prices dropped interest rates would fall and bond prices would rise. Evidently, this offsetting is less likely to be effective if bond rates are initially near zero.

${ }^{120}$ Stein (2013) notes that there is a growing market for collateral transformation, providing the opportunity to temporarily upgrade the quality of collateral through borrowing. However, this development implies higher "unwind risks" raising the possibility that the gains from meeting the regulatory requirements are in fact illusory. 
policies have interfered with normal processes of price discovery in many markets, and policy changes have been associated with waves of Risk-On and Risk-Off trading. ${ }^{121}$ More research is clearly needed on the possible negative effects of all these policy measures taken in aggregate.

Finally, it must be noted that post-crisis regulations have been tightened for non-bank financial institutions as well as banks. ${ }^{122}$ In part, this reflects the fact that the "shadow banking system" made a significant contribution to the crisis itself. The development of long intermediation chains, prone to "procyclicality" 123 and inherently fragile, resulted in a run to safety when one link of that chain (the capacity of mutual funds to always return 100 cents on the dollar) was called into question. Structured finance vehicles, which were part of that chain, then had to receive support from their sponsoring banks. However, since then, the use of these structured finance vehicles has essentially stagnated. ${ }^{124}$ Moreover, regulatory measures have been taken to reduce the likelihood of runs on mutual funds. The FSB was likely right when it recently concluded "Those aspects of non-bank financial intermediation that contributed to the financial crisis have declined significantly and generally no longer pose financial stability risk." 125

While it is comforting to note that old problems will not recur, the FSB also noted that major changes had occurred in the nature of non-bank financial intermediation since the crisis. This raises the possibility of new problems arising. Looking only at those institutions deemed to have "bank like" exposures, that could therefore pose a similar threat to financial stability, the FSB noted the rapid growth of Collective Investment Funds ${ }^{126}$ and, in particular, asset management companies. The total assets of non-bank financial intermediaries have grown by 50 percent since 2008. Developments in the United States have spearheaded this change, although similar developments have been observed in Europe and China.

The head of the FDIC in the US has also drawn attention to a massive shift in the structure of the US mortgage market, away from banks and towards non-bank originators and service providers. ${ }^{127}$ While she asked what the associated risks might be, she did not venture any

\footnotetext{
${ }^{121}$ See European Central Bank (2019). They find that, after the beginning of the Asset Purchase Program (APP), lower rates induced banks, and especially non-banks, to purchase more risky assets than had been the case prior to the APP. A combination of "more flighty" investors, acting individually in a still more "flighty" way, could imply disorderly price movements should rates start to rise. The ECB notes that the problem might be further exacerbated by a possible rise in risk aversion in such circumstances.

${ }^{122}$ It is beyond the scope of this paper to deal with the prospective health of pension funds and insurance companies, and the role played by regulatory changes. However, CGFS (2018) suggests both sectors are facing formidable challenges arising in part from the post-crisis environment of very low rates of interest.

123 See Singh and Aitken (2010)

124 See Financial Stability Board (2019a)

${ }^{125}$ Financial Stability Board (2018). Duffie (2016) seems to agree when he writes "The biggest achievement in the area of shadow banking is the new set of rules governing money market mutual funds." So called CNAV (constantnet-asset-value funds) will only be able to invest in government assets. In contrast, Partnoy (2020) states that big US banks still use off- balance sheet vehicles ("variable interest entities") to hold assets backed by commercial mortgages. Such assets might be under increased strain due to the pandemic.

${ }^{126}$ These include open ended fixed income funds, credit hedge funds and money market mutual funds. These funds have features that make them susceptible to runs.

${ }^{127}$ McWilliams (2018). The proportion of mortgages initiated by non-banks rose from 9 percent in 2009 to 44 percent in 2018. For mortgage servicing, the increase was from 5 percent to 41 percent.
} 
answer. ${ }^{128}$ Seru (2019) confirms that the share of household lending and mortgage lending extended by "fintech shadow banks" has risen very sharply, and adds that the expansion in the US has been greatest in those US counties where bank regulation has been tightened the most. Seru concludes that more attention needs to be paid to how both regulatory and monetary policies affect the business models of lenders. Further, since fintech shadow banks have global scope, global authorities should also be involved.

While the FSB has highlighted the growth of non-bank financial intermediaries, it has nevertheless concluded that "the FSB has not identified other new financial stability risks from shadow banking that would warrant additional regulatory action at the global level."129 However, this assessment has not been universally shared. Recently, the editor of the Banker magazine suggested that we run "the risk of a rerun of the financial crisis, this time led by non-banks." 130 Moreover, early in 2019, at least three senior European central bankers (including Mario Draghi) stated publicly that the shadow banking system remained a source of worry and that regulators lacked the tools to deal with this problem. ${ }^{131}$

A particular concern has been expressed over asset management companies that promise same day redemptions while at the same time investing heavily in non-liquid assets. This latter tendency has been aggravated by the very low rates of return available on more liquid assets. Mark Carney, former Governor of the Bank of England, eloquently summed up his concerns by saying "These funds are built on a lie, which is that you can have daily liquidity for assets that fundamentally aren't liquid." As with banks and mutual funds in earlier cycles, this maturity mismatch invites runs by investors ${ }^{132}$ and "fire sales" by the funds themselves. These observations support the view of the FSB that future developments in the area of non-bank financial intermediation need to be closely monitored.

Finally, considerable attention has also been paid recently to the rapid rise in lower quality corporate debt, and the growing importance of non-bank financial intermediaries in both originating such debt and in ultimately holding it. In a case study contained in Financial Stability Board (2019b), it is contended that the level of loans made to highly leveraged corporates could be as high as $\$ 2.4$ trillion, and that "junk" bonds issued by corporates now amounts to $\$ 2.3$ trillion. These numbers far exceed those seen pre-crisis. Moreover, within the universe of investment grade bonds, the proportion of bonds issued at the lowest grade has risen markedly, in both the US and Europe. Increasing the likelihood of systemic risk, the covenants on loans

\footnotetext{
${ }^{128}$ One specific concern has been raised in The Economist (2018). The article notes that many mortgage service providers could go bankrupt in the next downturn. Should this happen, what might be the implications of many mortgage payments not being serviced for an extended period of time? This question has risen in importance since the start of the pandemic since the proportion of commercial tenants not paying rent has risen sharply.

${ }^{129}$ Financial Stability Board (2017b).

${ }^{130}$ Caplen (2019). While his article was motivated by developments in China, Caplen feels regulators outside of China are the most remiss in not seeing the dangers arising from financial exposures outside the banking system.

${ }^{131}$ Reported in Jenkins (2018). A broader set of concerns relates to the explosive growth and almost total lack of transparency of private equity firms. See State Street Global Advisors (2018).

132 This possibility was confirmed in late June 2019 by heavy redemptions in the shares of six UK funds managed by $\mathrm{H} 2 \mathrm{O}$, an asset management company owned by Natixis Investment Managers. In contrast, early fears about fund withdrawals and fire sales during the pandemic did not materialize. In Europe, however, there was a sharp increase in the number of gated funds.
} 
made to debt-heavy corporations have weakened, almost to the point of non-existence. ${ }^{133}$ This threatens not only the probability of default but also recovery rates.

The primary driver for these developments has likely been the very low interest rate environment and the associated search for yield. However, a secondary element has been more onerous regulatory requirements on banks. These may have reduced the willingness of banks to make riskier loans and increased their desire to securitize the loans they did make. A prominent feature of recent developments has been the tendency for specialized companies to buy leveraged loans, to tranche them (Collateralized Loan Obligations) and then to sell a significant proportion of them to others. ${ }^{134}$ Evidently, there are some worrisome similarities between these market developments and those affecting sub-prime mortgages in the United States in the last crisis. ${ }^{135}$

One set of concerns has to do with the implications for corporate borrowers. Leverage levels have risen sharply, especially when the proceeds of the borrowing have been used to pay out dividends or buy in equity. ${ }^{136}$ In a downturn those firms could prove vulnerable to default, at worst, or a ratings downgrade at best. Rollover risk could also rise sharply. The rapid expansion of corporate debt in emerging markets, with much of it denominated in dollars, adds another element of uncertainty about the ability to meet debt service requirements.

The implications for lenders are also of concern. Ratings downgrades for borrowers could imply forced sales (by lenders with ratings limits) of those bonds now rated in the lowest category of investment grade. There are also a variety of reasons to expect market liquidity to suffer in such circumstances. ${ }^{137}$ As for leveraged loans, these markets are commonly illiquid and the lack of covenants might further impede the ability of lenders to cut their losses. The FSB (2019b) has recently concluded that banks, especially large global banks, have the largest exposures to both leveraged loans and CLOs, but that the participation of non-banks has been rising. The conclusion they draw is not comforting. "Given data gaps, a comprehensive assessment of the system-wide implications of the exposures of financial institutions to leveraged loans and CLOs is challenging."

\section{Do We Need a Fundamental Rethink?}

\footnotetext{
${ }^{133}$ Financial Stability Board (2019a) Section 5.2.2 notes that covenant lite loans were 80 percent of the total in 2018 versus less than 20 percent in the pre-crisis period.

${ }^{134}$ Private equity firms play a big role at all levels of this process. They take over companies using funds provided by banks. They then issue bonds in large volumes and set up separate vehicles to package them up and tranche them for sale to buyers with different risk appetites. The proceeds of the sales are than used to pay down the original funding by banks. Note the exposure of banks if the last stage cannot proceed as planned.

${ }^{135}$ It is a fact that no top-rated senior level of debt issued by a CLO has ever defaulted. Looking forward, however, concerns remain that highly rated upper tranches of these CLOs might still be subject to significant default risk, as were CDOs earlier. CLOs assume that the correlation of credit losses across diverse sectors will be relatively low. The pandemic has given even greater cause to question this assumption.

${ }^{136}$ Many bond issues have been associated with takeovers of companies by private equity firms. There are credible reports that leverage levels have been underestimated by overestimating the cost saving and prospective profits arising from the takeover.

${ }^{137}$ In addition to the general points about market liquidity made above, Smith (2018) points out that markets in CLOs might be particularly affected since retail investors are now involved via mutual funds and ETF's. Retail sales would spark illiquidity problems since bank loan markets do not trade frequently and settlement can take weeks.
} 
The seriousness of each of the concerns raised in this paper might be debated. Taken all together, however, they point to the conclusion that post-crisis international financial regulation still "falls short." The stability of the financial sector, much less the economy more generally, is still far from assured. This ineffectiveness might, in itself, provide adequate grounds for suggesting a fundamental rethink of the international regulatory framework is required.

Yet another consideration provides even stronger grounds for new thinking. The analysis above confirms that post-crisis regulatory initiatives have once again prompted market adaptation and the generation of problems elsewhere in the financial system. Given the "fiat money" system that currently prevails, this is inevitable. The system is not only complex (various assets can have money-like qualities) but also highly adaptive.

The problem begins with banks who create leverage in the normal course of business. However, leverage can suddenly be judged excessive, leading to bank "runs" that can be very costly. That is why the authorities have introduced "safety nets" to reduce the chance of such runs. However, a problem is created by this solution since safety nets produce "moral hazard". ${ }^{138}$ That is, they encourage more bad behavior to which officials have to respond with "regulation". But this regulation in turn creates another problem, as just noted, that of "evasion" and the threat of runs elsewhere in the system. The authorities then respond by widening the safety net, ${ }^{139}$ and then this leads to another whole cycle of public and private sector interactions. At each stage, complexity is increased and so too is the inherent instability of the system.

In short, the current regulatory framework is not only ineffective, it is unsustainable. Of course, these are very similar to the criticisms made above of how monetary policy is being currently conducted. Such fundamental considerations suggest the need for a rethink of how best to stabilize our economic system and how best to mitigate the particular problem of credit driven "booms and busts".

In response to this range of problems, a range of solutions have already been suggested in the literature. They are listed here, broadly in an order corresponding to how easy it would be to implement them. It is presumed that it would be easiest to change national policies, less easy to change the behavior of market participants and still less easy to change the structure of the domestic financial system. To change the monetary regime would be the most radical, and therefore the most difficult, domestic change of all. And still more difficult would be getting international agreement on what should replace the current international monetary non-system.

As a practical matter, this logic recommends the introduction of a macrofinancial stability framework, complemented by solutions to specific identified problems. This builds on existing institutional structures in an incremental way. More radical solutions addressed to the underlying problem of "fiat money" are also discussed, although only briefly. Unfortunately, it can be argued that the same order might also imply beginning with incremental reforms that are the

\footnotetext{
${ }^{138}$ See Colomiris and Chen (2019).

${ }^{139}$ In fact, this has been going on for decades. See White (2004). For a recent example, consider the expanded access of liquidity support to bank holding companies and mutual funds in the US during the last crisis. Looking forward, asset management companies and private equity companies might accept more regulation to get access to support from the public sector. If so, the safety net will have widened again.
} 
least effective, and only then proceeding to the more fundamental reforms really required. Political processes, both national and international, will inevitably determine where we end up in this trade off between practicality and effectiveness.

Beginning with changed policies, the first thing to suggest is that individual countries would be better served by adopting a macrofinancial stabilisation framework in which both monetary and regulatory polices "lean" against the credit cycle. As a corollary, all policies (monetary, regulatory and fiscal) should be used more symmetrically over each individual cycle. That would be required to stop the buildup of stocks of debt, both private and public, over time.

Recognizing that even this improved framework has shortcomings, identified above, it would also be prudent to complement it with policies directed to changing the behavior of lenders. There should be greater reliance on self discipline and market discipline. Excessive risk taking could be met with judicial penalties directed more to individuals than to corporations. ${ }^{140}$ As well, interest deductibility (for taxes) and limited liability in the financial sector should both be ended. Market discipline requires better numbers, that can only be provided through wholesale change in accounting (especially fair-value accounting) and auditing (especially dealing with the Big Four). ${ }^{141}$ In principle, and equally important, efforts should be made to change the behavior of borrowers so that they properly evaluate the longer run consequences of increasing their debt levels. An important step would be to severely limit share buybacks, particularly using money acquired through issuing more debt. ${ }^{142}$

Further complementary proposals have been made to use legislation to change the structure of the financial system. As Vickers (2017) has noted "besides the Volcker rule, there has been remarkably little serious structural reform anywhere else." A highly contentious issue is whether financial globalization, securitization and consolidation have all brought problems in their wake that exceed their benefits. Each could, in principle, be rolled back. International subsidiaries (separately capitalized) might replace branches. Securitization could be resisted through reducing the importance of collateral (as opposed to anticipated cash flow) in making lending decisions. Breaking up big financial firms would deal with the problem of "too big to fail."

Some critics of the current system remain skeptical that the changes recommended above, introducing a macrofinancial stability framework and measures to change behavior, could be made to work effectively. For example, those who emphasize that the economy is a complex, adaptive system could easily conclude that policymakers simply lack the knowledge to "lean against the wind." As noted above, the fallback position for many such critics is the imposition of a very much higher capital ratio. As a practical matter, the changes recommended above should likely be complemented by higher capital requirements as well.

Still others, even more pessimistic about the efficacy of all the proposals made above, have suggested the need for a much more radical approach to national monetary systems and to the

\footnotetext{
${ }^{140}$ Goodhart (2017).

${ }^{141}$ KPMG, Ernst and Young, Deloitte and PricewaterhouseCoopers.

${ }^{142}$ For a convincing set of arguments along these lines, see Smithers (2019). Goodhart and Lastra (2020) propose a number of ways to reduce corporate risk taking, not least the withdrawal of limited liability for those equity holders "with the power to monitor and control the corporation."
} 
international financial system itself. Within this group, a wide variety of views can again be identified.

Beginning with national monetary systems, some advocate "free banking." They suggest that financial regulation should be swept away and the provision of safety net support by central banks severely limited. The stability of the financial system would be ensured by market discipline, with banks making imprudent loans being reined in by other banks fearing the systemic fallout.

A different suggestion is made by those that advocate "narrow banking", some variant of the original proposal made by the Chicago School in the 1930s. In the original version, banks would have to hold government securities as backing for all current accounts. They would therefore lose their capacity to create money, and to drive credit "booms and busts." Instead all risky loans would be financed by true savings, and each loan would bear a direct risk of loss. More modern versions ${ }^{143}$ also address the so called "boundary problem"; namely, that non-banks could create substitutes for narrow money. Technological developments have made this much more likely than in the 1930's. As with "free banking," financial regulation and safety nets would be swept away. $^{144}$

Barring a decision, jurisdiction by jurisdiction, to retreat into autarky, all proposals for change at the national level will have to face an international challenge. For virtually every country other than the US, the decision to adopt unilaterally a macrofinancial framework could have important implications for exchange rate movements. Arguably, the decision in recent years by the Swedish Riksbank, the Bank of Canada and others, not to use monetary policy to lean more heavily against a worrisome increase in house prices and household debt, has reflected such concerns.

Similarly, proposed regulatory changes at the national level will immediately raise questions about international competitiveness and level playing fields. That is why the Basel led process of international regulatory guidelines has been so influential in recent decades. As for unilateral changes to the national monetary regime, that will raise a whole host of questions. The defeat in June 2018 of the Sovereign Money Initiative ("narrow money") in Switzerland was apparently due, in part at least, to widespread fears of going it alone.

Lurking behind all the problems identified in this paper, and all the proposed solutions, is an inconvenient reality. We do not have an international monetary system with rules which try to preserve economic stability at the international level. ${ }^{145}$ Absent such rules, every country can pursue its own short run interests, regardless of the longer run implications for systemic stability. The massive increase in the size of the balance sheets of all the world's most important central

\footnotetext{
${ }^{143}$ An unusually comprehensive approach is suggested by McMillan (2014). See also the many publications of Laurence Kotlikoff on "Limited Purpose Banking."

${ }^{144}$ However, note an important difference. Under "free banking" getting rid of regulations (that encourage bad behavior) and safety nets (that do the same) would be a precondition for systemic stability. Under "narrow banking," imprudent behavior would no longer be possible and so regulations and safety nets would be redundant.

${ }^{145}$ See Pringle (2012) and Ocampo (2017) for thoughtful suggestions for reform.
} 
banks, over the last decade and particularly since the onslaught of the pandemic, could be a dangerous case in point. The recourse by the US in 2018 to substantial fiscal stimulus, with the US economy already near full employment and its external position worsening, is another. The continued reliance of a number of European countries on external demand to support their economies must also be questioned. Unfortunately, there is never much political appetite to subject national policies to some form of international discipline. Moreover, given rising international geopolitical tensions today, that appetite is likely to be even more suppressed. 


\section{References}

Abad, J. and J. Suarez. (2017) "Assessing the cyclical implications of IFRS 9 - a recursive model”. ESRB Occasional Paper Series No 12.

Acharya. V., L. Pedersen, T. Phillipon and M. Richardson. (2010) "Measuring systemic risk". NYU Stern Working Paper.

Admati, A. and M. Hellwig. (2013) The Bankers New Clothes Princeton University Press, Princeton and Oxford.

Adrian, T., H. Dong, N. Liang and F. Natalucci. (2019) "Monitoring Global Financial Stability" IMF Blog, 26 August.

Adrian, T. and J. Kiff. (2018) "Market liquidity, leverage and regulation ten years after the crisis" VOX, 1 December.

Adrian, T., J. Kiff and H. S. Shin. (2018) "Liquidity, leverage and regulation 10 years after the global financial crisis." 1-24 Annual Review of Financial Economics, 10.

Adrian, T. and C. Pazarbasioglu. (2020) "Combatting COVID-19: How should banking supervisors respond?” IMF Blog, 15 June.

Aldasoro. I., T. Ehlers and E. Eren. (2018) "Business models and dollar funding of global banks.” BIS Working Papers No. 708, Basel.

Andrews, D., M. A. McGowan and V. Millot. (2017) "Confronting the zombies: Policies for productivity revival” Economic Policy Paper No 21, OECD, Paris

Antilla, S. (2018) "Wall Street moves to gut post-crisis financial rules" The Intercept, 2 November.

Atkeson, A. and P. J. Kehoe. (2004) "Deflation and depression: Is there an empirical link?" American Economic Review 94(2), pp99-103.

Banerjee, R. and B. Hoffman. (2018) "The rise of zombie firms: causes and consequences" BIS Quarterly Review, September.

Barwell, R. (2013) Macroprudential Policy Palgrave Macmillan, New York.

Basel Committee on Banking Supervision. (2010a) "Basel 3: A global regulatory framework for more resilient banks and banking systems" Basel.

Basel Committee on Banking Supervision. (2010b) "Basel 3: International framework for liquidity risk measurement, standards and monitoring" Basel.

Basel Committee on Banking Supervision. (2017) "Finalizing post-crisis reforms” Basel. 
Benink, H. (2019) "Global bank capital and liquidity after 30 years of Basel Accords" Journal of Risk and Financial Management, 17,73. 16 April.

Berner, R. (2018) “The next financial crisis: Are we safer?” Darden Investment Conference, 18 , November.

Bernholz, P. (2006) "Monetary regimes and history: Economic and political relationships" MPF Books.

Blundell-Wignal. A., G. Wehinger, and P. Slovik. (2009) "The elephant in the room: the need to deal with what banks do" OECD Journal, Financial Market Trends, Issue 2.

Blundell-Wignal, A. and C. Roulet. (2013) "Business models of bank leverage and distance to default" OECD Journal, Financial Market Trends, Issue 2.

Bordo, M. and C. M. Meissner. (2016) "Fiscal and financial crises" Prepared for Handbook of Macroeconomics vol.2, NBER Working Paper 22059, March.

Borio, C. (2003) "Towards a Macroprudential Framework for Financial Supervision and Regulation” BIS Working Papers No. 128, Basel, February.

Borio, C. (2014) "Monetary policy and financial stability: what role in prevention and recovery?" BIS Working Papers No.440, Basel, January.

Borio, C. E. V. and P. Lowe. (2002) "Asset prices, financial and monetary stability: Exploring the nexus" BIS Working Papers 114, Basel.

Borio, C., E. Kharroubi, C. Upper, and F. Zampolli. (2015) "Labour Reallocation and productivity dynamics: financial causes, real consequences" BIS Working Papers No. 534, Basel.

Borio, C. E.V., P. Disyatat, M. Juselius, and P. Rungcharoenkitkul. (2018) "Monetary policy in the grip of a pincer movement" BIS Working Papers No. 706, Basel.

Borio, C., P. McGuire and R. McCauley. (2020) "FX swaps, hidden debt, lurking vulnerability" VoxEU.org, 13 February.

Borio, C., M. Farag and N. Tarashev. (2020) "Post-crisis international financial regulatory reforms: a primer" BIS Working Papers No. 859, Basel.

Buiter, W. H. (2018) "The financial system ten years after the financial crisis: Lessons learned" Presentation at a meeting of the NAEC group, OECD, Paris, 25 September.

Buttiglione, L., P. R. Lane, L. Reichlin and V. R. Reinhart. (2014) "Deleveraging? What deleveraging?" $16^{\text {th }}$ Geneva Report on the World Economy, International Center for Monetary and Banking Studies, Geneva. 
Caplen, B. (2019) “China's slowdown: don't blame Trump” The Banker, Editor's Blog, 12 February.

Ceccetti, S. and K. Schoenholz. (2019) “What Risk Professionals Want” Blog, 11 March.

Cerutti, E., S. Claessens and L. Laeven. (2016) "The use and effectiveness of macroprudential policies" Bank for International Settlements, Working Papers No. 86, Basel, September.

Cerutti, E. and S. Claessens and L. Laeven. (2018) "The increasing faith in macroeconomic policies" Vox, 18 September.

CGFS (2016) "Fixed income market liquidity” Report 55, Bank for International Settlements, Basel.

CGFS (2018) "Financial stability implications of a prolonged period of low interest rates" Report 61, Bank for International Settlements, Basel, 5 July.

CGFS (2020) "US dollar funding: an international perspective” CGFS Papers No. 65, Basel, June.

Colomiris, C. and S. Chen. (2019) "The spread of deposit insurance and the global rise in bank asset risk since the 1970's” Recent Briefs in Economic Policy No. 144. The Cato Institute, 2 January.

Committee on International Economic Policy and Reform. (2011) "Rethinking Central Banking” Washington DC, September.

Dagher, J. (2018) "Regulatory cycles: revisiting the political economy of financial crises" Working Paper No. 18/8, International Monetary Fund, Washington DC, 15 January.

Dizard, J. (2015) “The next financial crisis: I told you so, and it isn't my fault" Financial Times, 4 May.

Dizard, J. (2019) “A clearing house crisis will pose a particular threat to Europe" Financial Times 28 February.

Domanski, D. (2018) “Towards effective global resolution regimes" Remarks by the Secretary general of the Financial Stability Board, 12 June.

Domanski, D., L. Gamabacorta and C. Picillo. (2015) "Central clearing: trends and issues" BIS Quarterly Bulletin, December, Basel.

Duffie, D. (2016) "Financial regulatory reform after the crisis: An assessment" ECB Forum on Central Banking 27-29 June.

Eatwell, J. and L. Taylor. (2000) Global finance at risk: The case for international regulation Polity Press. 
Edge, R. E. and N. Liang. (2019) "New financial stability governance structures and central banks" Brookings Report, 21 February.

European Central Bank. (2019) “ The Eurosystem asset purchase programme, risk taking and portfolio rebalancing” Financial Stability Review, May, Frankfurt.

Faruqui, U., W. Huang and E. Takats. (2018) “ Clearing risks in OTC derivatives markets: the CCP-bank nexus" BIS Quarterly Bulletin, December.

Feldberg, G. (2018) "Don't dismantle the post-crisis early warning system” Brookings Report, The Brookings Institution, 21 November, Washington.

Fernandez de Lis, S. (2016) "New requirements for loss absorbing capacity: TLAC and MREL" Capital Management Forum, London, 8 March.

Finance Watch. (2018) “Ten years after: Back to business as usual” 15 September.

Financial Stability Board. (2009) “The Financial Crisis and Information Gaps” Basel, October.

Financial Stability Board. (2011) "Key attributes of effective resolution regimes for financial institutions" Basel, November.

Financial Stability Board. (2017a) "FSB publishes policy recommendations to address structural vulnerabilities from asset management activities” Basel, 12 January.

Financial Stability Board. (2017b) "FSB publishes assessment of shadow banking activities and the adequacy of policy tools" Basel, 3 July.

Financial Stability Board (2018) "Report to the G20 Leaders on progress in financial regulatory reforms" Basel, 28 November.

Financial Stability Board. (2019a) "Global monitoring report on non-bank financial intermediation 2018” Basel, 4 February.

Financial Stability Board. (2019b) "Vulnerabilities associated with leveraged loans and collateralised loan obligations" Basel, 19 December.

Ford, J. (2018) “The illusion of UK bank capital strength” Financial Times, 11 March.

Goodhart. (2011) The Basel Committee on Banking Supervision: a history of the early years 1974-1997. Cambridge University Press.

Goodhart, C. A. E. (2013) "From national towards European/Global regulation" in 50 years of money and finance: Lessons and Challenges. Edited by M. Balling and E. Gnan, Larcier, Vienna.

Goodhart, C. A. E. (2017) "Guest Post: Why regulators should focus on banker's incentives" Bank Underground, Bank of England, 5 April. 
Goodhart, C. A. E. and D. Schoenmaker. (2019) "Automatic stabilisers in banking capital" VOX, 11 July.

Goodhart, C. A. E. and R. M. Lastra. (2020) "A partnership model is a way to restrain excessive risk taking" Financial Times, 30 June.

Group of Thirty. (2015) "Fundamentals of central banking: lessons from the crisis" Washington DC, October.

Group of Thirty. (2018) "Managing the next financial crisis" Washington DC, September.

Haley, J. (2020) "Macro foundations for macroprudential policy: a survey and assessment" Centre for International Governance Innovation, Waterloo, Canada, 21 January.

Huizinga, H. and L. Laeven. (2019) "The procyclicality of banking in the euro area" VOX, 29 May.

Isaac, W. M. and T. P. Vartanian. (2020) “How regulators can kick COVID-19's bank shock into remission" BankThink, 17 March.

Jackson, P. and U. Birchler. (2012) "The future of bank capital” Central Banking Journal, 24 September.

Jenkins, P. (2018) Policymakers share blame for the shadow banking boom" Financial Times, 10 January.

Jenkins, P. (2019) "Not just a Japanese disease: Mizuho's woes afflict the world" Financial Times.

J P Morgan. (2019) “A path forward for CCP resilience, recovery and resolution” 24 October.

Keen, S. (1995) “Finance and economic breakdown: modelling Minsky's financial instability hypothesis" Journal of Post-Keynesian Economics, Vol.17, No. 4, Summer, pp 607-635.

Keen, S. (2017) Can we avoid another financial crisis? Polity Press, Cambridge, UK.

Keynes, J. M. (1961) The general theory of money, interest and prices Macmillan and Company, London.

Kindleberger, C. P. and R. Z. Aliber. (2005) Manias, panics and crashes: a history of financial crises Fifth Edition, Palgrave Macmillan, New York.

Kirman. A. (2011) Complex Economics: Individual and collective rationality Routledge, February.

Kohn, D. (2020) “Stress tests: A policymaker's perspective” Brookings Report, 5 February.

Koo, R. (2003) Balance sheet recession Wiley. 
Kulati, E. W. and C. A. Hartwell. (2018) "Post crisis regulation through a critical lens" CASE, 8 September.

Kurella, V. (2019) “Don't have too much faith in our central banking superheros" Financial Times, 20 June.

Leung, J. (2015) "The tides of capital” OMFIF, London.

Littan, R. E. (2011) “The political economy of financial regulation after the crisis” Mimeo, December.

Lynch, D. J. (2020) "Here's one more economic problem the government's response to the virus has unleashed: Zombie firms." Washington Post, 23 June.

Masters, B. (2019) "This is a dangerous time to deregulate banks" Financial Times, 28 August.

McKinsey \& Company. (2019) "Signs of stress in the Asian financial system" McKinsey Global Institute, July.

McMillan, J. (2014) The end of banking: money, credit and the digital revolution Zero/One Economics, Zurich.

McWilliams, J. (2018) "Remarks" Fourth Annual Financial Stability Conference at The Office of Financial Research and the University of Michigan's Center on Finance, Law and Policy, Washington D C, 15 November.

Meadows, D. (1997) “Leverage points: Places to intervene in a system” Sustainability Institute.

Mester, J. (2015) "Post crisis financial system regulation and its research foundation" Presentation at Financial Intermediation Research Society Conference, Reykjavik, Iceland, 25 May.

Mian, A. (2019) "How to think about finance” Research Brief, Economists for Inclusive Prosperity, January.

Minsky, H. P. (1986) Stabilizing an unstable economy Yale University Press, New Haven. Ocampo, J. A. (2017) Resetting the International Monetary (Non) System Oxford University Press, Oxford.

OECD (2015) "Final NAEC system report” New Approaches to Economic Challenges, Paris, 3 June.

OECD (2020) "Averting systemic collapse" New Approaches to Economic Challenges, Paris, 27 February. 
OECD (2020) "The financial system" New Approaches to Economic Challenges, Paris, September.

Partnoy, F. (2020) "The looming bank collapse” The Atlantic, 11 June.

Powell, J. R. (2018) “The Federal Reserve's framework for monitoring financial stability" Presentation at the Economic Club of New York.

Pringle, R. (2012) “The Money Trap” Escaping the Grip of Global Finance” CPI Antony Rowe, Chippenham and Eastbourne.

Reinhart, C. and K. Rogoff (2009) Princeton University Press.

Reinhart, C. and V. Reinhart. (2010) "After the fall" in Macroeconomic challenges: the decade ahead. Federal Reserve Bank of Kansas, Kansas City.

Sargent, T. J. and N. Wallace. (1981) "Some unpleasant monetarist arithmetic" Federal Reserve Bank of Minneapolis Quarterly Review 5(Fall), pp 1-17.

Sarin, N. and L. H. Summers. (2016) "Have big banks gotten safer?" Brookings Papers on Economic Activity BPEA Conference Draft, 15- 16 September.

Schularick, M. and A. Taylor. (2012) "Credit Booms gone bust: Monetary policy, leverage cycles and financial crises 1870-2008” American Economic Review 102(2): 1029-1061.

Scott, H. (2016) Connectedness and contagion: Protecting the financial system from panics MIT Press, Cambridge Mass.

Seru, A. (2019) "Regulating banks in the era of fintech shadow banks" The Andrew Crocket Memorial Lecture, Bank for International Settlements, Basel, 30 June.

Shadow Financial Regulatory Committees of Asia, Australia-New Zealand, Europe, Japan, Latin America and the United States. (2013) "Misdiagnosis of crisis has led to botched liquidity regulation" Joint Statement No. 10, Tokyo, 28 October.

Singh, M. and J. Aitken. (2010) "The sizable role of rehypothecation in the shadow banking system" IMF Working Paper 10/172, Washington, July.

Smith, C. (2018) “Who’s buying leveraged loans anyway?” FT Alphaville, 13 December.

Smithers, A. (2019) Productivity and the bonus culture Oxford University Press.

Stafford, P. (2019) "Volatility spike prompts reforms at equity-options clearing house" Financial Times, 19 March.

State Street Global Advisors. (2018) "Boom in private markets is no private matter" Executive summary. 
Stein, J. C. (2013) " Overheating in credit markets: origins, measurement, and policy response" At the research symposium Restoring household financial stability after the Great Recession: Why household balance sheets matter._Sponsored by the Federal Reserve Bank of St. Louis. St Louis, Missouri.

Stramaglia, M. (2020) "Regulatory forbearance in the age of Covid-19” Global Risk Institute, Toronto, May.

Tarullo, D. K. (2016) "Financial regulation since the crisis" Remarks at Financial Stability Conference organized by the Federal Reserve Bank of Cleveland and Office of Financial Research Washington, 2 December.

Thakor, A. V. (2018) "Post crisis regulatory reform in banking: Address insolvency risk not liquidity” Journal of Financial Stability Vol. 37 C, pp107-111

The Economist (2014) "The slumps that shaped modern finance” Essay, 12 April.

The Economist (2018) "Japanese banks foreign exposure may threaten financial stability" 25 September.

The Economist (2018) "Homing in" 1 December.

The Economist (2019) “Clearing houses: Flight to safety” 1 June.

Tucker P (2014) “The political economy of macroprudential regimes” In Macroprudentialism A VoxEu.org eBook, Edited by D Schoenmaker, CEPR

Tucker, P. (2018) "Is the financial system sufficiently resilient?" Presentation at the BIS Annual Conference on Ten years after the great financial crisis: What has changed? Zurich, June.

Turner, A. (2016) Between debt and the devil Princeton University Press.

Veron, N. (2020) "Is the United States reneging on international financial standards?" Breugel Institute, Brussels, April.

Vickers, J. (2017) “Banking reform nine years on” Vox, 18 September.

White, W. R. (2004) “Are changes in financial structure extending safety nets?” BIS Working Papers No. 145, Basel, January

White, W. R. (2005) "Procyclicality in the financial system: Do we need a macrofinancial stabilization framework?" Kiel Institute for World Economics, September.

White, W. R. (2006) “Is price stability enough?” In Festschrift Die Schweizerische Nationalbank 1907-2007. Swiss National Bank. Also available as BIS Working Papers No. 205, Basel, April. 
White, W. R. (2009) "Should monetary policy "lean or “clean”?” Federal Reserve Bank of Dallas, Globalization and Monetary Policy Institute, Working Paper No 34, Dallas, August.

White, W. R. (2014) "The prudential regulation of financial institutions: Why regulatory responses to the crisis might not prove sufficient" Economics Department Working Paper No. 1108, OECD, Paris.

White, W. R. (2016) “Ultra-easy money: Digging the hole deeper?” Business Economics, Vol. 51, Issue 4, pp188-202, October.

White, W. R. (2017) "Conducting monetary policy in a complex, adaptive economy: Past mistakes and future possibilities” Credit and Capital Markets, Vol. 50, Issue 2, pp 213-235.

White, W. R. (2019a) “The limits of macroprudential policy” The International Economy, Winter.

White, W. R. (2019b) “Global debt risk: Are we prepared for the next crisis?” The Market, 25 April.

Wigglesworth, R. (2019) “Liquidity is the scary absentee in stocks' rebound" Financial Times 15 March.

Wigglesworth, R. (2019) “Are markets somehow broken?” Financial Times, 14 June.

Wolf, M. (2010) "Basel III, the Mouse that Did Not Roar," Financial Times, September 13.

Woodford, M. (2015) "Quantitative easing and financial stability” National Bureau of Economic Research Working Paper 22285, May.

Yellen, J. L. (2019) "Seven questions for Janet Yellen on financial stability” Brookings Up Front, 3 January. 